Draft Manuscript for Review

\title{
Geochemical evolution of arc and slab following subduction initiation: a record from the Bonin Islands, Japan
}

\begin{tabular}{|c|c|}
\hline Journal: & Journal of Petrology \\
\hline Manuscript ID & JPET-Feb-20-0021.R2 \\
\hline Manuscript Type: & Original Manuscript \\
\hline $\begin{array}{r}\text { Date Submitted by the } \\
\text { Author: }\end{array}$ & 27-Apr-2020 \\
\hline Complete List of Authors: & $\begin{array}{l}\text { Ishizuka, Osamu; National Institute of Advanced Industrial Science and } \\
\text { Technology Geological Survey of Japan, } \\
\text { Taylor, Rex; University of Southampton Faculty of Natural and } \\
\text { Environmental Sciences } \\
\text { Umino, Susumu; Kanazawa University Graduate School of Natural } \\
\text { Science and Technology } \\
\text { Kanayama, Kyoko; Tottori Prefecture }\end{array}$ \\
\hline Keyword: & $\begin{array}{l}\text { subduction initiation, boninite, geochemistry, Bonin Islands, Izu-Bonin- } \\
\text { Mariana arc }\end{array}$ \\
\hline
\end{tabular}

\section{SCHOLARONE Manuscripts}




\section{Geochemical evolution of arc and slab following subduction initiation: a record from the}

\section{Bonin Islands, Japan}

3

$33 *$ corresponding author 


\section{ABSTRACT}

Volcanism following the initiation of subduction is vital to our understanding of this specific magma-generation environment. This setting is represented by the first development of the IzuBonin-Mariana arc system as subduction commenced along the Western Pacific margin in the Eocene. A new collection of volcanics recovered from the islands and exposed crustal sections of the Bonin Ridge span the first $10 \mathrm{Myr}$ of arc evolution. An elemental and radiogenic isotope dataset from this material is presented in conjuction with new ${ }^{40} \mathrm{Ar} /{ }^{39} \mathrm{Ar}$ ages and a stratigraphic framework developed by a detailed mapping campaign through the volcanic sections of the Bonin Islands.

The dating results reveal that both the locus and type of magmatism systematically changed with time in response to the progressive sinking of the slab until the establishment of steadystate subduction at around 7-8 Myr. Following initial MORB-like spreading-related basalt magmatism, volcanic centres migrated away from the trench and changed from high-Si boninite to low-Si boninite/high-Mg andesite, then finally tholeiitic/calcalkaline arc magma.

Subducting pelagic sediment combined with Pacific-type igneous ocean crust dominate the slab input to the shallow source of high-Si boninites at $49 \mathrm{Ma}$, but high-precision $\mathrm{Pb}$ isotope data show that this sediment varies in composition along the subducting plate. At around 45 Ma, volcanism switched to low-Si boninite and the pelagic sediment signature was almost entirely replaced by volcanic or volcaniclastic material originating from a HIMU ocean island source. These low-Si boninites are isotopically consistent with a slab component comprising variable proportions of HIMU volcaniclastics and Pacific MORB. In turn, this signature was replaced by a Pacific MORB-dominated flux in the post $45 \mathrm{Ma}$ tholeiite and calcalkaline volcanics. Notably, each change in slab-derived flux coincided with a change in the magma type.

Fluctuations in the slab-derived geochemical signature were superimposed on a change in the mantle wedge source from highly-depleted harzburgite to a depleted MORB-type mantletype source. In turn, this may correspond to the increasing depth of the leading edge of the slab through this 5 Myr period. 


\section{INTRODUCTION}

Subduction initiation and the subsequent development of oceanic island arcs are poorly understood and remain an important unresolved problem in plate tectonics (e.g., Stern, 2004). Stern et al. (2012) emphasized the importance of studying forearc sections, which are not masked by younger sediment or accreted material from the subducting plate, to elucidate processes at subduction initiation. Recent geological and geophysical surveys of the trenchward Izu-Bonin-Mariana forearc, in sections such as the Bonin Ridge and SE of Guam, have revealed that their crustal stratigraphy was generated during the initial stages of arc formation (e.g., Ishizuka et al., 2006a, 2011a, 2014a; Reagan et al., 2010, 2017). These forearc crustal sections span $\sim 1200 \mathrm{~km}$ along the arc, yet have quite consistent stratigraphic sequences, which from bottom to top are: 1) gabbroic rocks, 2) a sheeted dyke complex, 3) basaltic lava flows, 4) lava flows, dykes and volcaniclastics of boninite and tholeiitic andesite, and 5) tholeiitic and calcalkaline basalt to andesite. In addition to the crustal section, dredge sampling and ROV dives recovered mantle peridotite beneath the gabbro. These observations indicate that almost all of the forearc crust down to Moho has been preserved in this forearc area.

Based on these subaerial and submarine studies of the trenchward forearc, processes at subduction initiation have to some extent become clearer. Subduction along the Izu-BoninMariana arc is estimated to have initiated at c. 52 Ma. The onset of slab sinking and the associated counterflow of asthenospheric mantle resulted in seafloor spreading on the overriding plate, which generated the first volcanism in the form of forearc basalts (FAB: Reagan et al., 2010). These eruptions are followed at $46-50$ Ma by boninitic magmatism, and then tholeiitic and calcalkaline magmatism at $\sim 44-45$ Ma. A comprehensive record of the boninitic and subsequent early arc tholeiitic to calcalkaline arc magmatism is preserved and exposed on the Bonin Islands (Umino, 1985; Umino \& Nakano, 2007; Umino et al., 2009, 2016; Kanayama et al., 2012, 2014).

This outline model for subduction initiation described above needs to be tested by determining the nature and composition of the subduction-derived material and the local subcrustal mantle during the magmatic development. Taylor et al. (1994) showed that boninites from the Chichijima Island have uniquely low $\mathrm{Sm} / \mathrm{Zr}$ and $\mathrm{Ti} / \mathrm{Zr}$, and along with other geochemical characteristics of boninites, they implied that slab melts with residual amphibole might contribute to boninite magma as well as a variably depleted mantle source. Kanayama et al. (2012) also found that the same processes generated the boninites from the Mukojima Islands. Umino et al. $(2015,2018)$ analysed primitive melt inclusions in chrome spinel and recognised two types of boninite magma. Temperature-pressure conditions for primary boninites, which range from $1345^{\circ} \mathrm{C}$ at $0.56 \mathrm{GPa}$ to $1421^{\circ} \mathrm{C}$ at $0.85 \mathrm{GPa}$ for the $46-48 \mathrm{Ma}$ low- 
$104 \mathrm{Si}$ and high-Si boninites, and $1381^{\circ} \mathrm{C}$ at $0.85 \mathrm{GPa}$ for the $45 \mathrm{Ma}$ low-Si boninite. They suggested that at 46-48 Ma, introduction of slab fluids induced melting of the residue of preceding basaltic magmatism (FAB) and high-temperature harzburgite, resulting in the low-Si and high-Si

107 boninites, respectively. By $45 \mathrm{Ma}$, convection within the mantle wedge brought the less108 depleted residue of FAB and depleted MORB-type mantle (DMM) into the region fluxed by 109 slab fluids, which melted to yield the less-depleted low-Si boninite, and more fertile arc basalts, 110 respectively.

111 The composition of early arc magmatism is also a function of the proportions and nature of 112 components added from the slab; such components may change as subduction progresses. To 113 unravel the temporal admixtures of mantle and subduction components therefore requires a 114 comprehensive elemental and isotopic dataset of volcanics that span the established 115 stratigraphic framework of early arc magmatism. This contribution presents new geochemical 116 dataset as well as ${ }^{40} \mathrm{Ar} /{ }^{39} \mathrm{Ar}$ ages for samples from the entire volcanic history of the Bonin 117 Islands. These data are used to establish the geochemical evolution of early arc magmatism, 118 and investigate the processes operating during the establishment of a new subduction zone.

\section{GEOLOGICAL BACKGROUND}

The Izu-Bonin arc marks the eastern margin of the Philippine Sea plate and is formed by westward subduction of the Pacific plate (Fig. 1a). This arc extends from southern Honshu to

124 the south of Io-to Island, and continues further south as the Mariana arc. Izu-Bonin arc has a broad volcanic zone extending in an east-west direction and is bounded by the Izu-Ogasawara Trench to the east and the Shikoku Basin to the west. Between $25^{\circ} \mathrm{N}$ and $29^{\circ} \mathrm{N}$, there is a prominent N-S trending forearc massif called the Bonin Ridge in an area between the

128 Quaternary volcanic front and Izu-Ogasawara Trench (Fig. 1a,b). The Bonin Ridge is separated 129 from the volcanic front by the Ogasawara Trough, which rifted in the Eocene or Oligocene (Fig. 130 1b; Taylor, 1992; Ishizuka et al., 2006a). This preserved the Bonin Ridge as an intact terrain 131 without any effects from later overlapping magmatism.

132

The subaerial Bonin Ridge

134

135 Bonin Islands sit atop an uplifted segment of the Bonin Ridge and expose a sequence of the 136 early Izu-Bonin arc volcanism (Fig. 2). The islands are geographically divided into 3 groups 137 (Fig. 1b): Mukojima Island Group (northern Bonin Islands), Chichijima Island Group (central 138 Bonin Islands) and Hahajima Island Group (southern Bonin Islands). The boninitic sequence, 
139 known as the Maruberiwan Formation, is the stratigraphically lowest unit exposed on the Bonin 140 islands (Fig. 2). This unit includes boninite, bronzite andesite, dacite and rhyolite (Umino, 141 1985; Umino \& Nakano, 2007), and is exposed on the Chichijima Island Group as well as the 142 Mukojima Island Group. Maruberiwan Formation boninites mostly classify as high-Si boninite 143 (Kanayama et al., 2012) and were formed in the Eocene between 46-48 Ma (Cosca et al., 1998; 144 Ishizuka et al., 2006a, 2011a). A quartz-bearing dacite-rhyolite sequence (Asahiyama 145 Formation; Umino, 1985) unconformably overlies the Maruberiwan Formation, however, no 146 significant time gap exists between the Asahiyama Formation and underlying boninitic rocks 147 (45.8 Ma: Ishizuka et al., 2011a). The youngest volcanics on the Chichjima Island Group are 148 the lavas and clastics of the Mikazukiyama Formation. These high-Mg two-pyroxene andesites 149 and low-Si boninites (Kanayama et al., 2012) unconformably overlie the rhyolites of the 150 Asahiyama Formation (Fig. 2; 44.3-44.74 Ma).

151 Tholeiitic to calcalkaline basaltic to andesitic rocks from Hahajima Island Group are the 152 youngest volcanic sequence exposed on any of the Bonin Islands (Fig. 2; Taylor \& Nesbitt, 153 1995; Ishizuka et al., 2006a; Kanayama et al., 2014; Umino et al., 2016). An ${ }^{40} \mathrm{Ar} /{ }^{39} \mathrm{Ar}$ age of $15444.0 \pm 0.3 \mathrm{Ma}$ has been reported for an andesite lava from Hahajima (Ishizuka et al., 2006a).

155

156 157

158

159

160

161

162

163

164

165

166

167

168

169

170

171

172

173

174

\section{Submarine section of the Bonin Ridge}

A recent investigation of the submarine section east of the Bonin Ridge has expanded the forearc stratigraphy to beneath that exposed on the Bonin Islands (Ishizuka et al., 2011a). This was found to consist of basalt lava flows and basaltic sheeted dykes, which were named forearc basalt (FAB) solely based on their current geographic location (Reagan et al., 2010). ${ }^{40} \mathrm{Ar} /{ }^{39} \mathrm{Ar}$ dating of these forearc basalts indicate an age between 48 and $52 \mathrm{Ma}$ (Ishizuka et al., 2011a). This predates the boninites and implies that the first magmatism following subduction initiation was produced at around 52 Ma. Zircon U-Pb ages of gabbro are 51.6 and 51.7 Ma, respectively, suggesting that the FAB and gabbros are co-magmatic (Ishizuka et al., 2011a).

$\mathrm{Li}$ et al. (2013) reported low-Ca (high-Si) boninite from Hahajima Seamount (ESE of Hahajima Island: Fig. 1b) with a ${ }^{40} \mathrm{Ar} /{ }^{39} \mathrm{Ar}$ age of $44 \pm 1.4 \mathrm{Ma}$. They argued that genesis of boninite involves melting of subducted volcaniclastic sediments derived from a HIMU seamount and Pacific slab as well as depleted Indian MORB-type mantle.

IODP Exp. 352 drilled in the Bonin forearc and recovered both forearc basalt and boninite at different Sites (Reagan et al., 2017, 2019; Shervais et al., 2019). The forearc basalt section reconfirmed that FAB magmatism initiated at around $52 \mathrm{Ma}$ (Reagan et al., 2019). Geochemical characteristics of the FAB imply that two stages of melting took place to produce FAB magma (Shervais et al., 2019). First stage melting is estimated to have occurred in the garnet stability 
175 field, probably hundreds of millions of years before subduction initiation (Yogodzinski et al., 176 2018). Second stage melting is estimated to be of a larger degree, occurring at higher 177 temperature and lower pressure $\left(1400-1480^{\circ} \mathrm{C}, 1-2 \mathrm{GPa}\right)$ compared to that for N-MORB.

178 Drilling also revealed that low-Si boninite erupted at 51.3 Ma with a clear slab-derived 179 signature (Li et al., 2019). Based on these results, Reagan et al. (2019) concluded that FAB 180 magmatism lasted for a short period of around 0.7 Myr. Subsequent supply of a slab-derived 181 flux initiated boninite magmatism from melting of the depleted mantle residue after FAB 182 extraction.

183

184 185

186

187

188

189

190

191

192

193

194

195

196

197

198

199

200

201

202

203

204

205

206

207

208

209

210

\section{Spatial variation of volcanism}

Forearc basalts are found on the inner trench wall of the Izu-Ogasawara Trench, i.e., the easternmost volcanic sequence in this area. A high-Si boninitic sequence younger than $48 \mathrm{Ma}$ occurs on the shallower slope of the inner trench wall, i.e., west of the forearc basalts and on the Bonin Islands. Post-44 Ma tholeiitic and calcalkaline lavas are exposed along the western escarpment of the Bonin Ridge, just west of the Bonin Islands where boninites occur, as well as on the Hahajima Islands (Ishizuka et al., 2006a). Thus, based on these observations, the locus of volcanism appears to have moved westward, i.e. away from the trench, with time (Ishizuka et al., 2011a). This may be related to the progressive establishment of subduction and a welldefined mantle wedge (e.g., Stern, 2004; Ishizuka et al., 2006a, 2011a). Extension of the overriding plate at subduction initiation might have controlled the location of the forearc basaltic volcanism (e.g., Stern \& Bloomer, 1992; Hall et al., 2003), and then cooling of the mantle wedge by the sinking slab, counter flow of asthenospheric mantle, and initiation of slab dehydration/melting all could have affected the focus of volcanism after $48 \mathrm{Ma}$ (e.g., Ishizuka et al., 2006a).

\section{SAMPLES STUDIED}

Samples used in this study were mainly collected during geological mapping campaigns on the Bonin Islands (Umino \& Nakano, 2007; Umino et al., 2009, 2015). They are representative of all subaerially exposed volcanics, and cover the entire age-range of magmatism exposed on the Bonin Islands (Fig. 2). High-Si boninite series rocks (Kanayama et al., 2012) were collected from the Mukojima Island and Chichijima Island Groups, reported in this contribution as Mukojima and Chichijima groups, respectively. Transitional high-Mg cpx-opx andesites and low-Si boninites (Kanayama et al., 2012) of the Mikazukiyama Formation were collected from Chichijima and Otoutojima, and described as Mikazukiyama group. Other younger basaltic to 
211 andesitic rocks were collected from the Hahajima Island Group (reported as Hahajima group). 212 Exact sample localities are listed in Tables S1-S5. For some of the samples from Mukojima, 213 Chichijima and Hahajima Island Groups, whole rock chemical compositions have been 214 published in Taylor et al. (1994), Kanayama et al. (2012, 2014) and Ishizuka et al. (2014b).

215 The samples used for analyses were selected from the much larger number of samples collected during the mapping campaign. Sample selection was mainly based on microscopic observation of thin sections and, in some cases, stereomicroscopic observation of rocks. Criteria for sample selection were; 1) The sample should mostly retain fresh groundmass, 2) Most of the phenocrysts are fresh, 3) Free from secondary mineral crystallisation (e.g., zeolites, opal) inside vesicles.

Specifically for ${ }^{40} \mathrm{Ar} /{ }^{39} \mathrm{Ar}$ dating, only high-Si boninites, which retain pristine glassy groundmass, were chosen. For samples from the Mikazukiyama group and Hahajima group, those with relatively crystalline groundmass composed of mainly plagioclase and pyroxene with only minor amounts of fresh interstitial glass were selected.

\section{ANALYTICAL PROCEDURES}

228

About $20 \mathrm{~g}$ of rock chips were ultrasonically cleaned with distilled water, and then crushed with an iron pestle and pulverised using an agate mortar. Whole rock major elements were analysed on glass beads, prepared by fusing 1:10 mixtures of $0.5 \mathrm{~g}$ subsamples and lithium tetraborate. The glass beads were analysed using a Panalytical Axios XRF spectrometer at the Geological Survey of Japan/AIST. External uncertainty and accuracy are generally $<2 \%$ (2.s.d), but $\mathrm{Na}$ could have as much as $\sim 7 \%$ analytical uncertainty. The data for each element are in agreement with accepted values and uncertainties of international standards (Table S1).

The rare-earth elements (REE), V, Cr, Ni, Rb, Sr, Y, Zr, Nb, Cs, Ba, Hf, Ta, Pb, Th and U concentrations were analysed by ICP-MS on a VG Platform instrument and Agilent 7900, both 239 dissolved in a HF-HNO 3 mixture (5:1) using screw-top Teflon beakers. After evaporation to 240 dryness, the residues were re-dissolved with $2 \% \mathrm{HNO}_{3}$ prior to analysis. In and Re were used 241 as internal standards, while JB2 with a similar level of dilution to the samples was used as an 242 external standard during ICP-MS measurements. Instrument calibration was performed using 243 5-6 calibration solutions made from international rock standard materials (including BIR-1, 244 BCR-1, AGV-1, JB1a, BEN). Reproducibility is generally better than $\pm 4 \%$ (RSD) for the REE, 245 and better than $\pm 6 \%$ (RSD) for other elements except those with very low concentration and $\mathrm{Ni}$ 246 (see BHVO2 analysis in Table S1). Detection limits vary from element to element, but for 
247 elements with low concentrations, such as REE and Ta, limits typically fall within a range from 0.2 to $2 \mathrm{pg} \mathrm{g}^{-1}$.

249

250

\section{Radiogenic isotopic composition}

251

252 Isotopic compositions of $\mathrm{Sr}, \mathrm{Nd}$, and $\mathrm{Pb}$ were determined on $500 \mathrm{mg}$ of hand-picked $0.5-1 \mathrm{~mm}$ 253 rock chips. The chips were leached in $6 \mathrm{M} \mathrm{HCl}$ at $140^{\circ} \mathrm{C}$ for $20-30$ minutes prior to dissolution in $\mathrm{HF}-\mathrm{HNO}_{3} . \mathrm{Sr}, \mathrm{Nd}$ and $\mathrm{Pb}$ isotope ratios were measured on a nine-collector VG Sector 54 mass spectrometer. Sr was isolated using Sr resin (Eichrom Industries, Illinois, USA). For Nd isotopic analysis, the REE were initially separated by cation exchange, before isolating $\mathrm{Nd}$ on Ln resin (Eichrom Industries, Illinois, USA) columns. Procedural $\mathrm{Sr}$ and $\mathrm{Nd}$ blanks were considered negligible relative to the amount of sample analysed. $\mathrm{Sr}$ and $\mathrm{Nd}$ isotopic compositions were determined as the average of 150 ratios by measuring ion beam intensities in multi-dynamic collection mode. Isotope ratios were normalised to ${ }^{86} \mathrm{Sr} /{ }^{88} \mathrm{Sr}=0.1194$ and 261 ${ }^{146} \mathrm{Nd} /{ }^{144} \mathrm{Nd}=0.7219$. Measured values for NBS SRM-987 and JNdi-1 (Tanaka et al., 2000) were ${ }^{87} \mathrm{Sr} /{ }^{86} \mathrm{Sr}=0.710278 \pm 19(2$ s.d., $\mathrm{n}=33)$ and ${ }^{143} \mathrm{Nd} /{ }^{144} \mathrm{Nd}=0.512104 \pm 10(2$ s.d., $\mathrm{n}=38)$ during the measurement period. All ${ }^{87} \mathrm{Sr} /{ }^{86} \mathrm{Sr}$ ratios were normalised to NBS SRM- $987{ }^{87} \mathrm{Sr} /{ }^{86} \mathrm{Sr}$ 264 $=0.710248$ (Thirlwall, 1991), and ${ }^{143} \mathrm{Nd} /{ }^{144} \mathrm{Nd}$ ratios were normalised to JNdi- $1=0.512115$ (Tanaka et al., 2000) as measured during the same analytical session.

The $\mathrm{Pb}$ isotopic compositions were determined at the Geological Survey of Japan/AIST and University of Southampton, UK. Average isotope ratio data from both laboratories was found 268 to be within $\sim 1$ s.d., and were within similar levels of uncertainty of the poly-spike SRM 981 values of Taylor et al., (2015). Consequently data presented are not internally adjusted or normalised. At the Geological Survey of Japan/AIST, Pb separation was achieved using AG1X8 200-400 mesh anion exchange resin. Procedural Pb blanks were $<30 \mathrm{pg}$, and considered 272 negligible relative to the amount of sample analysed. Pb isotopic measurements were made in 273 multi-dynamic collection mode using the double spike technique (Southampton-Brest-Lead 274 207-204 spike SBL74: (Ishizuka et al., 2003; Taylor et al., 2015)). Natural (unspiked) 275 measurements were made on $60-70 \%$ of collected $\mathrm{Pb}$, giving ${ }^{208} \mathrm{~Pb}$ beam intensities of $2.5-3 \times$ $27610^{-11} \mathrm{~A}$. Fractionation-corrected $\mathrm{Pb}$ isotopic compositions and internal errors were obtained by 277 a closed-form linear double-spike deconvolution (Johnson \& Beard, 1999). The reproducibility 278 of $\mathrm{Pb}$ isotopic measurements (external error: 2 s.d.) by double spike is $<200$ ppm for all $279{ }^{20 \times} \mathrm{Pb} /{ }^{204} \mathrm{~Pb}$ ratios. Measured values for NBS SRM-981 during the measurement period were 
${ }^{206} \mathrm{~Pb} /{ }^{204} \mathrm{~Pb}=16.9407 \pm 0.0039,{ }^{207} \mathrm{~Pb} /{ }^{204} \mathrm{~Pb}=15.5010 \pm 0.0050$, and ${ }^{208} \mathrm{~Pb} /{ }^{204} \mathrm{~Pb}=36.724 \pm 0.012$ (2 s.d., $\mathrm{n}=21$ ).

At the University of Southampton, rocks were prepared for $\mathrm{Pb}$ isotope analysis by initially crushing inside a plastic envelope using a non-torque press. Crushed material was then separated to $0.5-1.0 \mathrm{~mm}$ using a Teflon sieve set. This fraction was repeatedly cleaned with in ultra-pure water in an ultra-sonic bath. Cleaned rock-chips were then picked during microscopic examination. Samples were leached for $30-40$ min in $4 \mathrm{M} \mathrm{HCl}$ at $200^{\circ} \mathrm{C}$ prior to $\mathrm{Pb}$ separation using $\mathrm{HBr}-\mathrm{HCl}$ anion exchange columns. Lead isotope ratios were measured by a Thermo Neptune MC-ICP-MS at the University of Southampton UK, using a double spike run of each sample to correct for instrumental mass fractionation. The ${ }^{207} \mathrm{~Pb}-{ }^{204} \mathrm{~Pb}$ SBL74 spike was added such that ${ }^{204} \mathrm{~Pb}_{\text {sample }} / 204 \mathrm{~Pb}_{\text {spike }}$ was $0.09 \pm 0.03$. Procedural blanks range between $50-100 \mathrm{pg} \mathrm{Pb}$. NBS SRM 981 values achieved during the measurement period were ${ }^{206} \mathrm{~Pb} /{ }^{204} \mathrm{~Pb}=16.9406$ $\pm 0.0030,{ }^{207} \mathrm{~Pb} /{ }^{204} \mathrm{~Pb}=15.4980 \pm 0.0030,{ }^{208} \mathrm{~Pb} /{ }^{204} \mathrm{~Pb}=36.7188 \pm 0.0086$ (2s.d.; $\left.\mathrm{n}=17\right)$.

The Hf isotope ratios were measured on a Thermo Neptune MC-ICP-MS at the University of Southampton, UK. Hf isotope ratios were monitored and corrected for mass fractionation using ${ }^{179} \mathrm{Hf} /{ }^{177} \mathrm{Hf}=0.7325$ and for interferences using the values reported in Chu et al. (2002). Hf isotopes are reported relative to ${ }^{176} \mathrm{Hf} /{ }^{177} \mathrm{Hf}$ of JMC 475 of 0.282158 . Repeated JMC 475 measurements during the measurement period gave ${ }^{176} \mathrm{Hf} /{ }^{177} \mathrm{Hf}=0.282161 \pm 0.000010$ (2s.d.; $\mathrm{n}=26)$.

\section{${ }^{40} \mathrm{Ar} /{ }^{39} \mathrm{Ar}$ dating}

Ages of the fresh volcanic rocks were determined using the ${ }^{40} \mathrm{Ar} /{ }^{39} \mathrm{Ar}$ dating facility at the Geological Survey of Japan/AIST. Details of the procedures are reported in Ishizuka et al. (2009, 2018). 20-25 mg of phenocryst-free groundmass, crushed and sieved to $250-500 \mu \mathrm{m}$ in size, was analysed using a stepwise heating procedure. The samples were treated in $6 \mathrm{~N} \mathrm{HCl}$ for 30 minutes at $95^{\circ} \mathrm{C}$ with stirring to remove any alteration products (clays and carbonates) present in interstitial spaces. After this treatment, samples were examined under a microscope. Sample irradiation was done at the JRR3 and JRR4 reactors for 24 hours except for the sample 06062604C irradiated at the CLICIT facility of the Oregon State University TRIGA reactor for 4 hours. Sanidine separated from the Fish Canyon Tuff (FC3) was used as flux monitor and assigned an age of 27.5 Ma, which has been determined against the primary standard for our K-Ar laboratory, Sori biotite, the age of which is 91.2 Ma (Uchiumi \& Shibata, 1980).

$\mathrm{A} \mathrm{CO}_{2}$ laser heating system (NEWWAVE MIR10-30) was used in continuous wave mode 
314 for sample heating. A faceted lens was used to obtain a $3.2 \mathrm{~mm}$-diameter beam with 315 homogenous energy distribution to ensure uniform heating of the samples during stepwise heating analysis. Argon isotopes were measured on a VG Isotech VG3600 noble gas mass spectrometer fitted with a BALZERS electron multiplier except for sample 06062604C, which was measured on an IsotopX NGX noble gas mass spectrometer fitted with a Hamamatsu Photonics R4146 secondary electron multiplier in a peak-jumping mode.

Correction for interfering isotopes was achieved by analyses of $\mathrm{CaF}_{2}$ and $\mathrm{KFeSiO}_{4}$ glasses irradiated with the samples. The blank of the system including the mass spectrometer and the extraction line was $7.5 \times 10^{-14} \mathrm{ml} \mathrm{STP}$ for ${ }^{36} \mathrm{Ar}, 2.5 \times 10^{-13} \mathrm{ml} \mathrm{STP}$ for ${ }^{37} \mathrm{Ar}, 2.5 \times 10^{-13} \mathrm{ml} \mathrm{STP}$ for ${ }^{38} \mathrm{Ar}, 1.0 \times 10^{-12} \mathrm{ml} \mathrm{STP}$ for ${ }^{39} \mathrm{Ar}$ and $2.5 \times 10^{-12} \mathrm{ml}$ STP for ${ }^{40} \mathrm{Ar}$ with the VG3600 instrument, and $2.9 \times 10^{-14} \mathrm{ml} \mathrm{STP}$ for ${ }^{36} \mathrm{Ar}, 1.4 \times 10^{-13} \mathrm{ml} \mathrm{STP}$ for ${ }^{37} \mathrm{Ar}, 1.0 \times 10^{-14} \mathrm{ml} \mathrm{STP}$ for ${ }^{38} \mathrm{Ar}, 1.2 \times 10^{-14} \mathrm{ml} \mathrm{STP}$ for ${ }^{39} \mathrm{Ar}$ and $1.9 \times 10^{-12} \mathrm{ml} \mathrm{STP}$ for ${ }^{40} \mathrm{Ar}$ with the NGX mass spectrometer. Blank analyses were done every 2 or 3 step analyses. All errors for ${ }^{40} \mathrm{Ar} /{ }^{39} \mathrm{Ar}$ results are reported at one standard deviation. Errors for ages include analytical uncertainties

328

329

330

331

332

333

334

335

336

337

338

339

340

341

342

343

344

345

346

347

348

349 for Ar isotope analysis, correction for interfering isotopes, and $\mathrm{J}$ value estimation. An error of $0.5 \%$ was assigned to $\mathrm{J}$ values as a pooled estimate during the course of this study. Results of Ar isotopic analyses and correction factors for interfering isotopes are presented in the supplementary data (Table S6).

Plateau ages were calculated as weighted means of ages of plateau-forming steps, where each age was weighted by the inverse of its variance. The age plateaus were determined following the definition by Fleck et al. (1977). Inverse isochrons were calculated using York's leastsquares fit, which accommodates errors in both ratios and correlations of errors (York, 1969).

\section{RESULTS}

\section{${ }^{40} \mathrm{Ar} /{ }^{39} \mathrm{Ar}$ ages}

Six samples from the Hahajima group and one low-Si boninite from the Mikazukiyama group were dated by ${ }^{40} \mathrm{Ar} /{ }^{39} \mathrm{Ar}$ (Table 1; Fig. 3). Three samples from Hahajima gave ages between 40.2 and 45.28 Ma. For one sample (10093001-1), ${ }^{36} \mathrm{Ar} /{ }^{40} \mathrm{Ar}$ intercept of an inverse isochron plot does not agree with the atmospheric ratio within $2 \sigma$ error. However, this is because the data points form a tight cluster near the radiogenic end of the plot, and the ${ }^{36} \mathrm{Ar} /{ }^{40} \mathrm{Ar}$ intercept is not well constrained. The weighted average of ages of 13 steps can be regarded as a reliable eruption age for this sample. The ages from the Hahajima Island are stratigraphically consistent (Umino et al., 2016), i.e., two older samples (42.66 and $45.28 \mathrm{Ma}$ ) are from the lowermost Higashidai Formation and the youngest age (40.2 Ma) is from the uppermost Sekimon Formation (Fig. 2). Three Hahajima group samples from other islands of the Hahajima Island 
350 Group gave ages between 38.4 and 44.6 Ma, which are overlapping or slightly younger than 351 the ages from the Hahajima Island. Two samples (05122110 and 10092707-1) do not satisfy 352 the definition of "age plateau" in a strict sense. For these samples, higher temperature steps 353 which show decreasing ages as applied heating temperature increases appears to have been 354 affected by recoil, but lower to middle temperature steps show constant ages and seem to be 355 free from that effect. The weighted averages of the consecutive steps giving identical ages are 356 adopted as best estimate for the eruption ages, which are consistent with regional stratigraphy. 357 A low-Si boninite of the Mikazukiyama group from the Otoutojima island of the Chichijima 358 Island Group gave an age of 45.16 Ma, which is identical to the ages of cpx-opx andesites from 359 the same formation within the $2 \sigma$ uncertainty (Ishizuka et al., 2006a, 2011a).

360 361 362 363 364 365 366 367 368 369 370 371 372 373 374 375 376 377 378

\section{Major element compositions}

Volcanics from the Bonin Islands show mainly andesitic/intermediate $\mathrm{SiO}_{2}$ contents with some minor differentiated rocks including dacite and rhyolite, with basaltic rocks only present in the Hahajima group. Each volcanic group defines a distinct compositional range and trend on major element plots (Fig. 4). For example, taken at $8 \mathrm{wt} \% \mathrm{MgO}$, boninites from Mukojima and Chichijima have the highest $\mathrm{SiO}_{2}(58-60 \mathrm{wt} \%)$, Hahajima group the lowest $\mathrm{SiO}_{2}(50-55 \mathrm{wt} \%)$, with the cpx-opx andesites from the Mikazukiyama group at an intermediate level (Fig. 2, 4a). Mukojima and Chichijima boninites can be categorized as high-Si boninite (Kanayama et al., 2012).

In the Mikazukiyama group, boninites are the low-Si variety, whereas the cpx-opx andesites in this group have higher $\mathrm{SiO}_{2}$ and lower $\mathrm{MgO}$ than the boninites (Fig. 4a). Boninite series rocks are absent in the Hahajima group, and instead both tholeiitic and calcalkaline basalts to andesites are present (Fig. 4b).

$\mathrm{TiO}_{2}$ and $\mathrm{CaO}$ also show distinct trends among the different units. $\mathrm{CaO}$ and $\mathrm{TiO}_{2}$ at a given $\mathrm{MgO}$ are lowest in the high-Si boninites, moderate in the low-Si boninites and cpx-opx pyroxene andesites in the Mikazukiyama group, and highest in the Hahajima group (Fig. 2, $4 \mathrm{c}, \mathrm{d})$

379

\section{Trace element compositions}

381

382 Trace element ratios associated with fluid-mobile element enrichment are distinct among the 383 different volcanic units. All volcanics from the Bonin Islands show significantly lower $\mathrm{Ce} / \mathrm{Pb}$ 
384 relative to N-MORB (24.3: Gale et al., 2013: Fig. 5a) and most of the OIB (10-40: Willbold 385 and Stracke, 2006). High-Si boninites from the Chichijima and Mukojima groups show the lowest $\mathrm{Ce} / \mathrm{Pb}$, while the Hahajima group shows the highest (Fig. 5a). Mikazukiyama group 387 shows slightly higher $\mathrm{Ce} / \mathrm{Pb}$ than the high-Si boninites except for highly differentiated samples, which have $\mathrm{Ce} / \mathrm{Pb}>10$, and among the Mikazukiyama group, cpx-opx andesites generally have 389 lower $\mathrm{Ce} / \mathrm{Pb}$ (1.5-3) than low-Si boninite (3-11). Other fluid-mobile elements such as Ba show a similar variation in enrichment among the different volcanic units. For example, volcanics from the Bonin Islands show significantly higher $\mathrm{Ba} / \mathrm{Nb}$ relative to $\mathrm{N}-\mathrm{MORB}$ (around 10: Gale et al., 2013) and comparable or higher than OIB (4 -25: Willbold and Stracke, 2006). Ba/ $\mathrm{Nb}$ ratios are the highest for the high-Si boninites (30-130: Fig. 5b), while the Hahajima group shows the lowest $\mathrm{Ba} / \mathrm{Nb}$ (10-50). The Mikazukiyama group again shows intermediate ratios between the high-Si boninites and the Hahajima group (mostly 20-90), and cpx-opx andesites show higher $\mathrm{Ba} / \mathrm{Nb}$ than low-Si boninites.

Th enrichments yield different characteristics compared to those of the fluid-mobile elements. $\mathrm{Th} / \mathrm{Ce}$ or $\mathrm{Th} / \mathrm{Nb}$ (not shown) ratios are relatively high for the high-Si boninites and the Mikazukiyama group, and significantly higher than N-MORB (0.02 for Th/Ce, and 0.07 for $\mathrm{Th} / \mathrm{Nb}$ : Gale et al., 2013), and lower in the Hahajima group (Fig. 5c), comparable or slightly higher than N-MORB. Some of the cpx-opx andesites from the Mikazukiyama group show 402 particularly high $\mathrm{Th} / \mathrm{Ce}$ and $\mathrm{Th} / \mathrm{Nb}$.

Light rare earth element (LREE) ratios such as La/Sm also show differences between the 404 different groups, i.e., the high-Si boninites show the highest $\mathrm{La} / \mathrm{Sm}$, higher than N-MORB (1.2: Gale et a., 2013), and the Hahajima Group further extends to the lowest La/Sm ratios among the Bonin Islands volcanics, as low as comparable to N-MORB, while $\mathrm{La} / \mathrm{Sm}$ ratios in the Mikazukiyama group overlap with those of the high-Si boninites (Fig. 5d).

Middle to heavy rare earth element ratios such as $\mathrm{Dy} / \mathrm{Yb}$ are lowest in high-Si boninites, and the Hahajima group show the highest ratios, with intermediate ratios for both cpx-opx andesites and low-Si boninites from the Mikazukiyama group (Fig. 5e).

High-Si boninites have lower Sm/Zr than other volcanics from the Bonin Islands and NMORB (0.034: Gale et al., 2013). Low-Si boninites of the Mikazukiyama group show comparable ratios to the highest ratios amongst the high-Si boninites. The Hahajima group shows decreasing Sm/Zr with increasing Sm, while low-Si boninite and cpx-opx andesite of the Mikazukiyama group have increasing Sm/Zr with increasing Sm (Fig. 5f).

$416 \mathrm{Nb} / \mathrm{Zr}$ ratios of Bonin Island volcanics are generally lower than N-MORB (0.036). In the 
417 high-Si boninites this ratio is generally $0.012-0.02$, with some Mukojima group boninites 418 extending this to 0.035 . Most of the low-Si boninites from the Mikazukiyama group have higher $419 \mathrm{Nb} / \mathrm{Zr}$ ratios (0.02-0.035) than the high-Si boninites from Chichijima group, and overlap with 420 those of the Hahajima group (Fig. 5g).

421

\section{Radiogenic isotopes}

423

424

A clear feature of the $\mathrm{Pb}$ isotopes from the Chichijima and Mukojima high-Si boninites are the 425 positive trends extending from $\Delta^{207} \mathrm{~Pb} /{ }^{204} \mathrm{~Pb} \sim 2$ to 7 and $\Delta^{208} \mathrm{~Pb} /{ }^{204} \mathrm{~Pb} \sim 15$ to 30 , while ${ }^{206} \mathrm{~Pb} /{ }^{204} \mathrm{~Pb}$ varies from $\sim 18.5$ to $18.7\left(\Delta^{207} \mathrm{~Pb} / 204 \mathrm{~Pb}\right.$ and $\Delta^{208} \mathrm{~Pb} / 204 \mathrm{~Pb}$ are vertical deviation in ${ }^{207} \mathrm{~Pb} /{ }^{204} \mathrm{~Pb}$ and ${ }^{208} \mathrm{~Pb} /{ }^{204} \mathrm{~Pb}$ from the Northern Hemisphere Reference Line (NHRL: Hart, 1984; Zindler and Hart, 1986), Fig. 6a and b). In ${ }^{207} \mathrm{~Pb} /{ }^{204} \mathrm{~Pb}-\Delta^{207} \mathrm{~Pb} /{ }^{204} \mathrm{~Pb}$ (Fig. 6c), these groups form strong positive correlations extending to high ${ }^{207} \mathrm{~Pb} /{ }^{204} \mathrm{~Pb}$ (15.6). In each of these projections, samples from the Mukojima group form a discrete, sub-parallel trend to the Chichijima group, but are offset to $\sim 0.1$ higher ${ }^{206} \mathrm{~Pb} /{ }^{204} \mathrm{~Pb}$. In contrast, the Mikazukiyama low-Si boninites form a trend extending to high ${ }^{206} \mathrm{~Pb} / 204 \mathrm{~Pb}(19.5)$, low $\Delta^{208} \mathrm{~Pb} / 204 \mathrm{~Pb}(-30)$ and constant $\Delta^{207} \mathrm{~Pb} /{ }^{204} \mathrm{~Pb}$ ( -1.5). Mikazukiyama cpx-opx andesites form a short, steep trend close to the NHRL, but with ${ }^{206} \mathrm{~Pb} /{ }^{204} \mathrm{~Pb}$ decreasing with increasing $\Delta \mathrm{Pb}$. This trend is coincident with the upper "off-axis" boninites from IODP Exp. 352 (Fig. 6 a-c). The Hahajima group forms a compact group with similar ${ }^{206} \mathrm{~Pb} /{ }^{204} \mathrm{~Pb}$ and $\Delta^{207} \mathrm{~Pb} /{ }^{204} \mathrm{~Pb}$ to Pacific MORB, but with $\Delta^{208} \mathrm{~Pb} / 204 \mathrm{~Pb}$ elevated to $\sim 12$. Overall, the Hahajima group forms a diffuse trend to lower $\Delta$-values with higher ${ }^{206} \mathrm{~Pb} /{ }^{204} \mathrm{~Pb}$, in a similar fashion to the Mikazukiyama low-Si boninites. volcanics from the Bonin Islands. (Fig. 6d). The Hahajima group shows the lowest ${ }^{87} \mathrm{Sr} /{ }^{86} \mathrm{Sr}$ and highest ${ }^{143} \mathrm{Nd} /{ }^{144} \mathrm{Nd}$, while cpx-opx andesites and low-Si boninites of the Mikazukiyama group have intermediate ratios between high-Si boninites and the Hahajima group. Figure 6e shows that high-Si boninites from the Chichijima and Mukojima groups have a wide range of ${ }^{143} \mathrm{Nd} /{ }^{144} \mathrm{Nd}(\varepsilon \mathrm{Nd} \sim 2.5-7.5)$ at constant ${ }^{206} \mathrm{~Pb} /{ }^{204} \mathrm{~Pb}(18.65 \pm 0.1)$. This compares to Hahajima and Mikazukiyama, which have relatively invariant $\varepsilon \mathrm{Nd} \sim 6.5-8.5$; regardless of their spread in ${ }^{206} \mathrm{~Pb} /{ }^{204} \mathrm{~Pb}$ (18.4-19.5). Despite the spread of $\varepsilon \mathrm{Nd}$ on Chichijima there is little corresponding change in $\varepsilon H f(12.1-13.5)$, which contrasts with Hahajima and Mikazukiyama, where $\varepsilon H f$ is 449 dispersed in the range 11.3-17.5 (Fig. 6f). 


\section{Volcanism moves away from the trench}

452

453

454

455

456

457

458

459

460

461

462

463

464

465

466

467

468

469

470

471

472

473

474

475

476

477

478

479

480

481

482

New dating results presented in this study as well as those from IODP Exp. 352 (Reagan et al., 2019) support the earlier interpretations regarding the temporal variation of early arc magmatism (Ishizuka et al., 2006a; 2011a). Following the trench-proximal FAB at 51-52 Ma, magmatism progresses westwards across the arc. Reagan et al. (2019) showed that boninites drilled at U1439 of IODP Exp.352 on the trench slope east of the Mukojima Islands are 50.3351.27 Ma; 2 Myr older than subaerially-exposed boninites from the Bonin Islands. This result indicates that boninite magmatism started with the low-Si boninite, and then high-Si boninites at around $51 \mathrm{Ma}$ within c. $10 \mathrm{~km}$ from the FAB site (Reagan et al., 2019). Subsequently, the location of high-Si boninite magmatism migrated westward, i.e., toward the present day Bonin Islands, and this magmatism lasted around 4 million years until $46 \mathrm{Ma}$, to be followed by dacite and rhyolite magmatism of the Asahiyama Formation at 45-46 Ma (Table 1, Ishizuka et al., 2006a; 2011a). The Asahiyama volcanics can be viewed as a product of crystal fractionation of boninite magma (Taylor et al., 1994). Ages of the boninites thus imply that the locus of boninite magmatism migrated away from the trench with time.

Low-Si boninite and cpx-opx andesites of the Mikazukiyama group erupted at around $45 \mathrm{Ma}$, and lasted for less than a million years.

The youngest magmatism (38.4-45 Ma) occurred in the Hahajima group in the southern Bonin Islands, and along the western escarpment of the Bonin Ridge to the west off the Mukojima and Chichijima Islands (Ishizuka et al., 2006a). Furthermore, dredge sampling to the east of Hahajima Island (D30 of KH07-2 cruise; Fig. 1b) recovered boninites, confirming the east-west spatial sequence along this $350 \mathrm{~km}$ long segment of the arc. Dating results support for the interpretation that following subduction initiation, magmatism migrated about $80 \mathrm{~km}$ away from the trench with time, over a period of 7-8 million years.

\section{Changes in slab input}

Isotopic variations amongst the Bonin volcanics could have been generated by a number of potential sources. These are:

1) Pre-existing crust

2) Subducted pelagic or volcaniclastic sediment 
483

484

485

486

487

488

489

490

491

492

493

494

495

496

497

498

499

500

501

502

503

504

505

506

507

508

509

510

511

512

513

514

3) Subducted igneous ocean crust/lithosphere

4) The supra-subduction mantle (mantle wedge)

These components may contribute to the composition of the system either via a fluid, a melt or as a solid/melted assimilant. In the current Izu-Bonin-Mariana arc, there are good constraints on the isotopic composition and elemental abundances of most of these components (e.g., Hauff et al., 2003; Plank et al., 2007; Durkin et al., in press). In general terms at least, the recently subducted and current supra-subduction material are likely to be similar to those of the Eocene. As such, we assume that these compositions can be used to assess inputs to the Bonin Island volcanism. Recent drilling through the Eocene-Oligocene Izu-Bonin-Mariana rear-arc confirmed that pre-existing crust is equivalent to Indian MORB (i.e. Philippine Sea MORB: Hickey-Vargas et al., 1995) ocean crust (Ishizuka et al., 2018; Hickey-Vargas et al., 2018; Yogodzinski et al., 2018). As such, this pre-existing crust has similar Indian isotopic characteristics to the forearc basalts, indicating the mantle wedge was characterised by $\Delta^{208} \mathrm{~Pb} /{ }^{204} \mathrm{~Pb} \sim 40$ and $\Delta^{207} \mathrm{~Pb} / 204 \mathrm{~Pb} 0-3$.

Sedimentary components on the current Pacific plate span the age range of Bonin Island volcanism. These comprise pelagic sediments and seamount-derived volcaniclastic sediments, which are variably distributed along the length of the current arc (Kelley et al., 2003; Plank et al., 2007; Straub et al., 2009: Fig. 6). Some latitudinal variation is present in the sedimentary material, for example between ODP Sites 1149 and 801 of the Izu-Bonin and Mariana arcs, respectively (Plank \& Langmuir, 1998; Plank et al., 2007: Fig. 6). This may be reflected in the isotopic variation in $\mathrm{Pb}$ isotopes along the active Izu-Bonin-Mariana arc (Taylor \& Nesbitt, 1998; Ishizuka et al., 2006b, 2007).

Subducted altered ocean crust in the current system is Pacific MORB with seamounts of HIMU or EM composition (Koppers et al., 1998, 2003; Durkin et al., in press ). It is possible that Indian MORB compositions were present on the Pacific Plate in the Eocene, but have subsequently been consumed by subduction (Straub et al., 2009). Alteration by syn-magmatic hydrothermal processes and by seawater interaction may have modified primary magmatic compositions of volcaniclastic material and oceanic crust. Such processes generally increase U relative to $\mathrm{Th}$ and $\mathrm{Pb}$ which, as shown in Fig. 6 a-c and e, results in lower $\Delta^{207} \mathrm{~Pb} /{ }^{204} \mathrm{~Pb}$ and $\Delta^{208} \mathrm{~Pb} /{ }^{204} \mathrm{~Pb}$ (often highly negative) with higher ${ }^{206} \mathrm{~Pb} /{ }^{204} \mathrm{~Pb}$ (Hauff et al., 2003; Straub et al., 2009; Li et al., 2019).

Positive correlations between fluid-mobile element enrichment and isotopes, such as Ba and 
$515{ }^{87} \mathrm{Sr} /{ }^{86} \mathrm{Sr}$ and ${ }^{206} \mathrm{~Pb} / 204 \mathrm{~Pb}$, are indicative of radiogenic components added to a Indian MORB516 type mantle (Fig. 7a). This component has been interpreted as slab-derived material added to 517 the source of boninite magma from the subducting Pacific plate (e.g., Taylor et al., 1994; 518 Ishizuka et al., 2006a, 2011a; Li et al., 2019).

$519 \mathrm{~Pb}$ isotope variation within high-Si boninites from the Chichijima and Mukojima groups 520 defines a strong alignment between Pacific pelagic sediment with high $\triangle \mathrm{Pb}$ and Pacific MORB 521 or its altered, subducting equivalent with low $\Delta \mathrm{Pb}$ (Fig. 6a-c). The lack of a trajectory to high $522 \Delta^{208} \mathrm{~Pb} /{ }^{204} \mathrm{~Pb}$ with low ${ }^{206} \mathrm{~Pb} /{ }^{204} \mathrm{~Pb}$ excludes significant $\mathrm{Pb}$ derived from the Indian MORB 523 mantle wedge $\left(\Delta^{208} \mathrm{~Pb} /{ }^{204} \mathrm{~Pb}>30\right)$. Notably, Chichijima and Mukojima boninites have $\mathrm{Ce} / \mathrm{Pb}$ $524<2$ regardless of their $\mathrm{Pb}$ isotope ratio (Fig. 7 b). This implies that the components that mixed to 525 form the $\mathrm{Pb}$ isotope trends must also have similarly low $\mathrm{Ce} / \mathrm{Pb}$. Indeed, they have significantly 526 527 lower $\mathrm{Ce} / \mathrm{Pb}$ than subducting Pacific crust or Pacific pelagic sediment. This low $\mathrm{Ce} / \mathrm{Pb}$ is likely a characteristic of fluid released from the subducted crust, which derives its $\mathrm{Pb}$ from interaction 528 with variable proportions of MORB and sediment. As this Pb-rich fluid was introduced into an 529 effectively $\mathrm{Pb}$-free depleted mantle wedge, essentially the entire $\mathrm{Pb}$ inventory of the resulting 530 partial melts was slab-derived.

531 Correlations between $\varepsilon \mathrm{Nd},{ }^{206} \mathrm{~Pb} /{ }^{204} \mathrm{~Pb}$ and $\varepsilon \mathrm{Hf}$ for the high-Si boninites from the Chichijima 532 and Mukojima groups (Fig. 6e, f) are also indicative of pelagic sediment-Pacific MORB 533 interaction. However, the addition of $\mathrm{Nd}$ and $\mathrm{Hf}$ via subduction implies the carrier may have 534 the characteristics of a melt or supercritical fluid rather than a simple aqueous fluid (e.g., 535 536 Woodhead et al., 2001). This implication is further supported by a negative correlation between ${ }^{143} \mathrm{Nd} /{ }^{144} \mathrm{Nd}$ and $\mathrm{Th} / \mathrm{Ce}$ or La/Sm (Fig. 7c,d).

Taylor et al. (1994) proposed that the distinctively low $\mathrm{Sm} / \mathrm{Zr}$ of Chichijima boninites $(0.02$ compared to $\sim 0.035$ for MORB) resulted from slab melting in the presence of residual 539 540 amphibole, but not by crystal fractionation of amphibole. This interpretation appears to be applicable to all the high-Si boninites from the Chichijima and Mukojima groups (Fig. 5f). $541 \mathrm{Sm} / \mathrm{Zr}$ variation of the Hahajima group, however, seems to be compatible with (cryptic) crystal 542 fractionation of amphibole, as seen in mature volcanic arcs (e.g., Davidson et al., 2007), which 543 consistently explains $\mathrm{Sm} / \mathrm{Zr}$ variation with $\mathrm{Sm}$ content and also decreasing Dy/Yb with 544 increasing $\mathrm{SiO}_{2}$ (Fig. 5e, f).

545 After activity of Chichijima and Mukojima high-Si boninite magmatism, volcanism at 44-45 546 Ma became transitional between boninitic and tholeiitic/calc-alkaline. These eruptives are 547 represented by the low-Si boninites and cpx-opx andesites of the Mikazukiyama group. This 
548 switch in magmatism was accompanied by a sharp change in the characteristics of the 549 subduction components. Neither of the Mikazukiyama magma types show any significant 550 indication of $\mathrm{a} \mathrm{Pb}$ isotope vector towards pelagic sediment. Instead these volcanics trend to 551 negative $\Delta^{208} \mathrm{~Pb} /{ }^{204} \mathrm{~Pb}$ and high ${ }^{206} \mathrm{~Pb} /{ }^{204} \mathrm{~Pb}(18.8-19.5)$ compositions. Other characteristics, 552 such as lower $\mathrm{Th} / \mathrm{Ce}$ and ${ }^{87} \mathrm{Sr} /{ }^{86} \mathrm{Sr}$ combined with higher $\mathrm{Ce} / \mathrm{Pb}$ and ${ }^{143} \mathrm{Nd} /{ }^{144} \mathrm{Nd}$ (Fig. 6d, 7b,c) 553 are also concordant with a significantly smaller pelagic contribution. The overall implication 554 of this is that, in the central and southern Bonin islands at least, there was a change in the 555 material released from the slab at around $45 \mathrm{Ma}$. It is also possible that physical conditions in 556 the slab changed at the same time. This, in turn, may change the properties of the slab flux (e.g., 557 hydrous fluid, siliceous melt, supercritical fluid) and consequently influence the trace element 558 concentrations in the slab component (e.g., Kessel et al., 2005).

559 A possible candidate for a slab-derived component with high ${ }^{206} \mathrm{~Pb} /{ }^{204} \mathrm{~Pb}$ and low $\Delta \mathrm{Pb}$ is 560 volcaniclastic material originating from HIMU oceanic islands on the subducting Pacific Plate 561 (Koppers et al., 1998, 2003; Ishizuka et al., 2007). Since HIMU seamounts in the modern 562 Western Pacific are as old as 100-120 Ma (Koppers et al., 2003), it is reasonable to assume that 563 such volcaniclastics were present on the newly subducting Pacific Plate at $45 \mathrm{Ma}$. Contribution 564 of this volcaniclastic material instead of pelagic sediment is consistent with lower ${ }^{87} \mathrm{Sr} /{ }^{86} \mathrm{Sr}$ and 565 higher ${ }^{143} \mathrm{Nd} /{ }^{144} \mathrm{Nd}(\varepsilon \mathrm{Nd} \sim 6)$ in Mikazukiyama compared to the earlier high-Si boninites. Of 566 the two groups within Mikazukiyama, the low-Si boninites have higher $\mathrm{Nb} / \mathrm{Zr}, \Delta \mathrm{Nb}(\Delta \mathrm{Nb}$ is 567 defined as $\Delta \mathrm{Nb}=1.74+\log (\mathrm{Nb} / \mathrm{Y})-1.92 \log (\mathrm{Zr} / \mathrm{Y})$ to express deficiency or excess of $\mathrm{Nb}$ 568 relative to the OIB compositions: Fitton et al. (1997)) and ${ }^{206} \mathrm{~Pb} / 204 \mathrm{~Pb}$, suggesting they may 569 have a larger contribution from the HIMU volcaniclastics relative to the cpx-opx andesites (Fig. $5708)$.

572 A further change in the subduction system occurred with the Hahajima group, which followed 573 the Mikazukiyama group. Hahajima samples shift back to lower ${ }^{206} \mathrm{~Pb} /{ }^{204} \mathrm{~Pb}(18.5)$ at $574 \Delta \Delta^{207} \mathrm{~Pb} /{ }^{204} \mathrm{~Pb} \sim 0$ and higher ${ }^{143} \mathrm{Nd} /{ }^{144} \mathrm{Nd}(\varepsilon \mathrm{Nd} \sim 8)$, which is consistent with Pacific MORB-type 575 crust in the subduction flux (Fig. 6e). Hahajima is also characterised by a much subdued 576 enrichment in fluid-mobile elements (lowest $\mathrm{Ba} / \mathrm{Nb}$, highest $\mathrm{Ce} / \mathrm{Pb}$ among volcanics from the 577 Bonin Islands: Fig. 5a,b). Given the higher $\mathrm{Ce} / \mathrm{Pb}$ of Hahajima (5-12), it is possible that a 578 greater proportion of these trace elements were derived from melting of the Indian-MORB579 style mantle wedge $(\mathrm{Ce} / \mathrm{Pb} \sim 25)$ rather than the subduction fluid $(<2)$. This is also supported by 
580 its higher $\Delta^{208} \mathrm{~Pb} /{ }^{204} \mathrm{~Pb}(\sim 12)$ and $\varepsilon \mathrm{Hf}(16)$, which are transitional between the characteristics of

581 the Indian mantle domain and a subduction input dominated by Pacific MORB (Fig. 6b, f).

582

583

Slab derived material can take different physical forms, such as supercritical fluid, siliceous

584

585

586

587

588

589

590

591

592

593

594

595

596

597

598

599

600

601

602

603

604

605

606

607

608

609

610

611

612

melt or hydrous fluid. The physical properties are chiefly controlled by temperature (e.g., Kawamoto et al., 2012) as well as pressure and source mineral assemblage. Slab-derived material affecting the Quaternary Izu-Bonin frontal arc volcanoes appears to be dominated by hydrous fluid; except its southernmost part around Ioto Island (e.g., Taylor and Nesbitt, 1998; Ishizuka et al., 2007). Hence, a major difference between the earliest Eocene arc and the modern Izu-Bonin arc appears to be that a siliceous melt component was prominent and dominant in early arc relative to the modern arc, whatever the nature of the subducting materials. This might indicate that in the earliest subarc mantle was hotter at a shallower depth relative to the modern arc. Consequently, this allowed the generation of more siliceous melt directly from slab or from reactions between supercritical fluids and the mantle, which released melts with a high-Mg andesitic composition (e.g., Kessel et al., 2005; Mibe et al., 2011; Kawamoto et al., 2012).

\section{Nature of the subducting slab}

Bonin Islands magmatism describes the evolution of a nascent arc and indicates that there were a series of distinct changes in the subduction flux within a period of 4 million years (Fig. 9a-c). Following the Indian MORB-like forearc basalts, the initial high-Si boninite arc magmas at $\sim 48$ Ma reflect a flux of melt or supercritical fluid derived from subducted crust comprising accumulations of pelagic sediment on Pacific MORB (Fig. 9a, d).

Following this at $45 \mathrm{Ma}$, the slab flux briefly switched to originating from a combination of HIMU-style sediment and Pacific MORB, before Pacific-MORB became the dominant subduction input to the mantle wedge at 44 Ma. A transient HIMU signature such as this is compatible with a $30 \mathrm{~km}$ diameter seamount subducted at $4 \mathrm{~cm} /$ year, which would take $<1 \mathrm{Myr}$ to pass beneath the arc (Fig. 9b, d). This estimate is consistent with the short duration of Mikazukiyama group activity with a strong signature of ocean island volcano-derived material. After the seamount passed, it appears that the Pacific plate provided a negligible amount of sediment, because the Hahajima group are dominated by a signature of Pacific ocean crust (Fig. $9 \mathrm{c}, \mathrm{d})$. This lack of pelagic sediment after $45 \mathrm{Ma}$ might be explained by the following scenarios: 
613 in an environment not suitable for pelagic sedimentation. 2) Pelagic sediment was not 614 subducted because it was scraped off and accreted to the trench slope. 3) Subducting pelagic 615 sediment released its melt or fluid flux before it reached the melt generation depth for Hahajima. 616 Assuming that the Pacific plate was being subducted, a drastic change in the age of the crust 617 seems unlikely, except in the presence of hotspot-related seamounts. Variation of the CCD 618 could cause a variation in sediment thickness and composition via the abundance of biogenic 619 carbonate. Sedimentary carbonate could cause a dilution of all trace elements except $\mathrm{Sr}$ (and $\mathrm{Sr}$ 620 is not highly enriched in currently subducting Izu-Bonin carbonate sediment; Plank et al., 2007). 621 This implies that carbonate variation in the subducting sediment probably does not significantly 622 change the isotopic composition (at least for $\mathrm{Nd}$ and $\mathrm{Pb}$ ) of subducting sediment. Siliceous 623 biogenic sediment can also dilute the enrichment of continentally-derived pelagic clays and/or 624 625 sediments, hence should not affect the isotopic and trace element signature of subducting sediment.

626 Based on recent plate reconstruction models, the location of subduction nucleation for the Izu627 Bonin arc is predicted to have been far from continents (Seton et al., 2015: Wu et al., 2016). 628 Eurasia is the most likely source of terrigenous sediment, but its contribution is expected to 629 have been relatively small, and has not changed significantly in this time period. Accordingly, 630 it is hard to explain the lack of a sediment signature simply via compositional variation of the 631 subducting sediment: an absence of pelagic sediment seems more likely.

632 An extensional stress regime on the overriding plate (i.e., the Philippine Sea plate) generated 633 spreading and FAB magmatism during the initial stages of subduction. This extension appears 634 to have prevailed until the end of boninite magmatism at around $45 \mathrm{Ma}$ (Umino, 1985; Umino $635 \&$ Nakano, 2007). After $45 \mathrm{Ma}$, there is little evidence for the development of a parallel dyke 636 swarm. This implies a change in regional stress regime, i.e., a decreasing differential stress 637 between $\sigma 1$ and $\sigma 3$ in the horizontal plane, indicating a cessation of regional extension. This 638 change in the stress regime might have been linked to trench retreat and/or a variation in the 639 rate of convergence. In turn, these could potentially affect the rate of erosion or accretion at the 640 trench (e.g., Clift \& Vannucchi, 2004) and hence align with the second scenario above. Lower 641 crust and upper mantle are exposed along the Izu-Ogasawara Trench (Ishizuka et al., 2011; 642 Morishita et al., 2011), which implies that erosion or extension in the forearc has uncovered the 643 deepest arc. The timing of this exposure is not clear, but this implies that the Izu-Ogasawara 644 trench was erosional at some point after boninite magmatism, and the accreted sediment, if any, 645 could have been removed at any time between the Eocene and present. 
646 In terms of the third scenario, some evidence for dehydration of the slab in the forearc can be 647 taken from the occurrence of serpentinite derived from mantle harzburgite found in the Izu 648 forearc at ODP Sites 783 and 784 (Fryer et al., 1990: Ishii et al., 1992). Kamimura et al. (2002) 649 obtained a seismic velocity structure of the Izu forearc including the serpentinite-based 650 Torishima Seamount. They proposed that the low velocity in the forearc mantle corresponded 651 to serpentinised peridotite hydrated by dehydration of the subducting slab. Serpentinisation of 652 the forearc mantle is expected to occur below $600^{\circ} \mathrm{C}$, and hence be amagmatic (e.g., Hyndman 653 and Peacock, 2003; Ribeiro et al., 2019). Accordingly, even though the age of the 654 serpentinisation is not clear, sediment dehydration in the forearc without magmatism is a 655 possibility after $45 \mathrm{Ma}$.

656

The locus of magmatism appears to have migrated by about $80 \mathrm{~km}$ within 5 million years from 658 near the trench to the Bonin Islands. This does not simply mean that a specific point of the 659 subducting slab moved this distance away from the trench as slab flux clearly changed with time. However, if we assume a subduction angle of $45^{\circ}$ and a minimum subduction rate of 661 around 3-4 cm/year, this could explain the migration of volcanic activity. The slab depth is

662 663 664 665 666 667 668 669 670 671

672 673 674 675 676 677 678 expected to be greater than $40 \mathrm{~km}$, based on the depth estimate for melt extraction of boninites at $48 \mathrm{Ma}$ (by assuming that melt extraction occurred in the mantle wedge: Umino et al., 2015), which is consistent with the above estimate for the rate of subduction.

Since the locus of Eocene magmatism migrated away from the trench, the chemical composition of magmatism is likely to have been influenced by a progressively deeper release from the slab. At this time the mantle also was free of earlier metasomatism, i.e. the subduction flux was added to a "clean sheet" mantle source. Combining the progressive deepening and the initially flux-free mantle may explain why the nascent arc records sharp changes in the slab flux compared to the modern mature arc.

\section{CONCLUSION}

High-precision isotope data combined with ${ }^{40} \mathrm{Ar} /{ }^{39} \mathrm{Ar}$ dating constrain the chemical evolution of the Izu-Bonin system as it responded to the initiation of subduction. Volcanic activity migrated $80 \mathrm{~km}$ away from the trench over a period of 5 million years, in response to the progressive descent of the slab until the establishment of steady-state subduction.

1) Following initial spreading and MORB-like magmatism (50-52 Ma), and short period of 
679 activity of low-Si boninite near axis at $51 \mathrm{Ma}$, the nascent arc erupted high-Si boninite 680 adjacent to the trench (46-50 Ma). This progressed into low-Si boninite and cpx-opx 681 andesites (45 Ma), then tholeiitic and calcalkaline magmatism (38.4-45 Ma).

682 2) These changes in magma type coincided with sharp changes in the slab-derived flux. On 683 the Bonin Islands, initial high-Si boninites reflect a pelagic sediment and MORB-derived 684 flux. This was replaced by a HIMU-type volcaniclastic signature in the following low-Si 685 boninites. In turn, this signature was replaced by a Pacific MORB-dominated flux in the 686 post 45 Ma volcanics.

687 3) Trace element data suggest that the flux-free mantle wedge composition was initially a 688 harzburgitic, potentially residual following forearc basalt removal. At $45 \mathrm{Ma}$ this changed 689 to a less depleted mantle with characteristics similar to Philippine Sea MORB source.

690 4) Changes in slab-flux and mantle wedge composition may be a response to the unique and 691 transient conditions following subduction initiation. Subduction-free mantle in the nascent 692 693 694 695 696

\section{ACKNOWLEDGEMENTS}

697

We would like to thank K. Yamanobe for preparation of glass beads and assistance with the 699 ICP-MS measurements. We appreciate A. Owada, T. Sato and E. Hirabayashi for preparation 700 of thin sections. We also thank T. Sasaki, T. Shimono, A. Tokumoto, and H. Nagato for helping 701 preparation of rock powder, and N. Geshi and Y. Ishizuka for the maintenance of GSJ XRF 702 laboratory. Andy Milton and Agnes Michalik are thanked for assistance in the Southampton 703 isotope laboratories. We appreciate IMR, Tohoku University and Oregon State University for 704 neutron irradiation. This work was supported by Grant-in-Aid (B) (No. 25287133), (C) (No. 705 17K05686) and JSPS bilateral grant (Japan-UK) for OI. The authors acknowledge the 706 constructive reviews by anonymous reviewers and helpful editorial comments by Georg 707 Zellmer and Marjorie Wilson.

708

709 SUPPLEMENTARY DATA

710 Supplementary data are available at Journal of Petrology online.

\section{REFERENCES}


713

714

715

716

717

718

719

720

721

722

723

724

725

726

727

728

729

730

731

732

733

734

735

736

737

738

739

740

741

742

743

744

745

Blichert-Toft, J. \& Albarede, F. (1997). The Lu-Hf isotope geochemistry of chondrites and the evolution of the mantle-crust system. Earth and Planetary Science Letters 148, 243-258.

Chauvel, C., Marini, J.-C., Plank, T. \& Ludden, J. (2009). Hf-Nd input flux in the Izu-Mariana subduction zone and recycling of subducted material in the mantle. Geochemistry Geophysics Geosystems 10, $2008 \mathrm{GC} 002101$.

Chu, N. C., Taylor, R. N., Chavagnac, V., Nesbitt, R. W., Boella, R. M., Milton, J. A., German, C. R., Bayon, C. \& Burton, K. (2002). Hf isotope ratio analysis using multi-collector inductively coupled plasma mass spectrometry: an evaluation of isobaric interference corrections. Journal of Analytical Atomic Spectrometry 17, 1567-1574.

Clift, P. \& Vannucchi, P. (2004). Controls on tectonic accretion versus erosion in subduction zones: Implications for the origin and recycling of the continental crust. Reviews of Geophysics 42, RG2001, doi:10.1029/2003RG000127.

Cosca, M. A., Arculus, R. J., Pearce, J. A. \& Mitchell, J.G. (1998). ${ }^{40} \mathrm{Ar} /{ }^{39} \mathrm{Ar}$ and K-Ar geochronological age constraints for the inception and early evolution of the Izu-BoninMariana arc system. The Island Arc 7, 579-595.

Davidson, J. P., Turner, S., Handley, H., Macpherson, C. \& Dosseto, A. (2007). An amphibole 'sponge' in arc crust? Geology 35, 787-790.

Durkin, K., Castillo, P. R., Straub, S. M., Abe, N., Tamura, Y. \& Yan, Q. (in press). An origin of the along-arc compositional variation in the Izu-Bonin arc system. Geoscience Frontiers doi.org/10.1016/j.gsf.2019.12.004.

Fitton, J. G., Saunders, A. D., Norry, M. J., Hardarson, B. S. \& Taylor, R.N. (1997). Thermal and chemical structure of the Iceland plume. Earth and Planetary Science Letters 153, 197208.

Fleck, R.J., Sutter, J.F. \& Elliot, D.H. (1977). Interpretation of discordant ${ }^{40} \mathrm{Ar} /{ }^{39} \mathrm{Ar}$ age-spectra of Mesozoic tholeiites from Antarctica. Geochimica et Cosmochimica Acta 41, 15-32.

Fryer, P., Pearce, J. A., Stokking, L. B., et al. (1990). Proceedings of the Ocean Drilling Program Initial Reports: Ocean Drilling Program, College Station, TX, 125.

Gale A., Dalton, C. A., Langmuir, C. H., Su, Y. \& Schilling, J.-G. (2013). The mean composition of ocean ridge basalts. Geochemistry Geophysics Geosystems 14, doi:10.1029/2012GC004334.

Hall, C.E., Gurnis, M., Sdrolias, M., Lavier, L.L. \& Muellar, R.D. (2003). Catastrophic initiation of subduction following forced convergence across fracture zones. Earth and 
Planetary Science Letters 212, 15-30.

Hart, S. R. (1984). A large-scale isotopic anomaly in the Southern hemisphere mantle. Nature 309, 753-757.

Hauff, F., Hoernle, K. \& Schmidt, A. (2003). Sr-Nd-Pb composition of Mesozoic Pacific oceanic crust (Site 1149 and 801, ODP Leg 185): implications for alteration of ocean crust and the input into the Izu-Bonin-Mariana subduction system. Geochemistry Geophysics Geosystems 4(8),8913, doi:10.1029/2002GC000421.

Hickey-Vargas, R. (1991). Isotope characteristics of submarine lavas from the Philippine Sea: implications for the origin of arc and basin magmas of the Philippine tectonic plate. Earth and Planetary Science Letters 107, 290-304.

Hickey-Vargas, R., Hergt, J. M. \& Spadea, P. (1995). The Indian Ocean-type isotopic signature in Western Pacific marginal basins. In: Taylor B. \& Natland, J. (eds) Origin and significance in Active Margins and Marginal Basins of the Western Pacific. American Geophysical Union, Geophysical Monograph 88, 175-197.

Hickey-Vargas, R. (1998). Origin of the Indian Ocean-type isotopic signature in basalts from Philippine Sea Plate spreading centers: An assessment of local versus large-scale processes. Journal of Geophysical Research 103, 20963-20979.

Hickey-Vargas, R., Yogodzinski, G. M., Ishizuka, O., McCarthy, A., Bizimis, M., Kusano, Y., Savov, I. P. \& Arculus, R. (2018). Origin of depleted basalts during subduction initiation and early development of the Izu-Bonin-Mariana Island arc: Evidence from IODP Expedition 351 Site U1438, Amami-Sankaku Basin. Geochimica et Cosmochimica Acta 229, 85-111.

Hyndman, R. D. \& Peacock, S. M. (2003). Serpentinization of the forearc mantle. Earth and Planetary Science Letters 212, 417-432.

Ishii, T., Robinson, P. T., Maekawa, H. \& Fiske, R. (1992). Petrological studies of peridotites from diapiric serpentinite seamounts in the Izu-Ogasawara-Mariana forearc, Leg 125. Proceedings of the Ocean Drilling Program Scientific Results 125, 445-485.

Ishizuka, O., Taylor, R. N., Milton, J. A. \& Nesbitt, R. W. (2003). Fluid-mantle interaction in an intra-oceanic arc: constraints from high-precision $\mathrm{Pb}$ isotopes. Earth and Planetary Science Letters 211, 221-236.

Ishizuka, O., Kimura, J., Li, Y., Stern, R., Reagan, M., Taylor, R., Ohara, Y., Bloomer, S., Ishii, T. \& Hargrove III, U. (2006a). Early stages in the evolution of Izu-Bonin arc volcanism: new age, chemical, and isotopic constraints. Earth and Planetary Science Letters 250, 385401. 
779 Ishizuka, O., Taylor, R. N., Milton J. A., Nesbitt, R. W., Yuasa, M. \& Sakamoto, I. (2006b). 780 Variation in the source mantle of the northern Izu arc with time and space -Constraints from 781 high-precision $\mathrm{Pb}$ isotopes -. Journal of Volcanology and Geothermal Research 156, 266290.

783 Ishizuka, O., Taylor, R. N., Milton J. A., Nesbitt, R. W., Yuasa, M. \& Sakamoto, I. (2007). 784 Processes controlling along-arc isotopic variation of the southern Izu-Bonin arc. 785 Geochemistry Geophysics Geosystems 8, Q06008, doi:10.1029/2006GC001475.

786 Ishizuka, O., Yuasa, M., Taylor, R. N. \& Sakamoto, I. (2009). Two contrasting magmatic types 787 coexist after the cessation of back-arc spreading. Chemical Geology 266, 283-305.

788 Ishizuka, O., Yuasa, M., Tamura, Y., Shukuno, H., Stern, R. J., Naka, J., Joshima, M. \& Taylor, 789 R. N. (2010). Migrating shoshonitic magmatism tracks Izu-Bonin-Mariana intra-oceanic arc 790 rift propagation. Earth and Planetary Science Letters 294, 111-122.

791 Ishizuka, O., Tani, K., Reagan, M. K., Kanayama, K., Umino, S., Harigane, Y., Sakamoto, I., 792 Miyajima, Y., Yuasa, M. \& Dunkley, D.J. (2011a). The timescales of subduction initiation 793 and subsequent evolution of an oceanic island arc. Earth and Planetary Science Letters 306, $794 \quad 229-240$.

795 Ishizuka, O., Taylor, R. N., Yuasa, M. \& Ohara, Y. (2011b). Making and breaking an Island 796 arc: a new perspective from the Oligocene Kyushu-Palau arc, Philippine Sea. Geochemistry 797 Geophysics Geosystems 12, Q05005, doi:10.1029/2010GC003440.

798 Ishizuka, O., Taylor, R. N., Ohara, Y. \& Yuasa, M. (2013). Upwelling, rifting and age799 progressive magmatism from the Oki-Daito mantle plume. Geology 41, 1011-1014.

800 Ishizuka, O., Tani, K. \& Reagan, M. K. (2014a). Izu-Bonin-Mariana fore-arc crust as a modern $801 \quad$ ophiolite analogue. Elements 10, 115-120.

802 Ishizuka, O., Umino, S., Taylor, R. N. \& Kanayama, K. (2014b). Evidence for hydrothermal 803 activity in the earliest stages of intraoceanic arc formation: implication to ophiolite-hosted 804 hydrothermal activity. Economic Geology 109, 2159-2177.

805 Ishizuka, O., Hickey-Vargas, R., Arculus, R. J., Yogodzinski, G. M., Savov, I. P., Kusano, Y., 806 McCarthy, A., Brandl, P. \& Sudo, M. (2018). Age of Izu-Bonin-Mariana arc basement. Earth 807 and Planetary Science Letters 481, 80-90.

808 Johnson, C. M. \& Beard, B. L. (1999). Correction of instrumentally produced mass 809 fractionation during isotopic analysis of $\mathrm{Fe}$ by thermal ionization mass spectrometry. $810 \quad$ International Journal of Mass Spectrometry 193, 87-99.

811 Kamimura, A., Kasahara, J., Shinohara, M., Hino, R., Shiobara, H., Fujie, G. \& Kanazawa, T. 
812 (2002). Crustal structure study at the Izu-Bonin subduction zone around $31^{\circ} \mathrm{N}$ : implications 813 of serpentinized materials along the subduction plate boundary. Physics of the Earth and 814 Planetary Interiors 132, 105-129, doi:10.1016/S0031-9201(02)00047-X.

815 Kanayama, K., Umino, S. \& Ishizuka, O. (2012). Eocene volcanism during the incipient stage 816 of Izu-Ogasawara Arc: Geology and petrology of the Mukojima Island Group, the 817 Ogasawara Islands. The Island Arc 21, 288-316.

818 Kanayama, K., Umino, S. \& Ishizuka, O. (2014). Shallow submarine volcano group in the early 819 stage of island arc development: Geology and petrology of small islands south off Hahajima 820 821 822 823 824 825 826 827 828 829 830 831 832 833 834 835 836 837 838 839 840 841 842 843 844 main island, the Ogasawara Islands. Journal of Asian Earth Sciences 85, 1-25.

Kawamoto, T., Kanzaki, M., Mibe, K., Matsukage, K. N. \& Ono, S. (2012). Separation of supercritical slab-fluids to form aqueous fluid and melt components in subduction zone magmatism. Proceedings of the National Academy of Sciences of the United States of America 109, 18695-18700.

Kelley, K. A., Plank, T., Ludden, J. \& Staudigel, H. (2003). Composition of altered oceanic crust at ODP Sites801 and 1149. Geochemistry Geophysics Geosystems 4(6), doi:10.1029/2002GC000435.

Kessel, R., Schmidt, M. W., Ulmer, P. \& Pettke, T. (2005). Trace element signature of subduction-zone fluids, melts and supercritical liquids at 120-180km depth. Nature 437(29), 724-727.

Koppers, A. A. P., Staudigel, H., Wijbrans, J. R. \& Pringle, M. S. (1998). The Magellan seamount trail: implications for Cretaceous hotspot volcanism and absolute Pacific plate motion. Earth and Planetary Science Letters 163, 53-68.

Koppers, A. A. P., Staudigel, H., Pringle, M. S. \& Wijbrans, J. R. (2003). Short-lived and discontinuous intraplate volcanism in the South Pacific: Hot spots or extensional volcanism? Geochemistry Geophysics Geosystems 4(10), doi:10.1029/2003GC000533.

Li, H. -Y., Taylor, R. N., Prytulak, J., Kirchenbaur, M., Shervais, J. W., Ryan, J. G., Godard, M., Reagan, M. \& Pearce, J. A. (2019). Radiogenic isotopes document the start of subduction in the Western Pacific. Earth and Planetary Science Letters 518, 197-210.

Li, Y. -B., Kimura, J. -I., Machida, S., Ishii, T., Ishiwatari, S., Maruyama, S., Qiu, N.-N., Ishikawa, T., Kato, Y., Haraguchi, S., Takahata, N., Hirahara, Y. \& Miyazaki, T. (2013). High-Mg adakite and low-Ca boninite from a Bonin fore-arc seamount: implications for the reaction between slab melts and depleted mantle. Journal of Petrology 54, 1149-1175.

Mibe, K., Kawamoto, T., Matsukage, K. N., Fei, Y. \& Ono, S. (2011) Slab melting versus slab 
dehydration in subduction-zone magmatism. Proceedings of the National Academy of Sciences of the United States of America 1088, 177-8182.

Miyashiro, A. (1974). Volcanic rock series in island arcs and active continental margins. American Journal of Science 257, 609-647.

Miyazaki, T., Kimura, J.-I., Senda, R., Bogdan, V., Chang, Q., Takahashi, T., Hirahara, Y., Hauff, F., Hayasaka, Y., Sano, S., Shimoda, G., Ishizuka, O., Kawabata, H., Hirano, N., Machida, S., Ishii, T., Tani, K. \& Yoshida, T. (2015). Missing western half of the Pacific Plate: Geochemical nature of the Izanagi-Pacific Ridge interaction with a stationary boundary between the Indian and Pacific mantles. Geochemistry, Geophysics, Geosystems 16, 3309-3332.

Plank, T. \& Langmuir, C. H. (1998). The chemical composition of subducting sediment and its consequences for the crust and mantle. Chemical Geology 145, 325-394.

Plank, T., Kelley, K. A., Murray, R. W. \& Stern, L. Q. (2007). Chemical composition of sediments subducting at the Izu-Bonin trench. Geochemistry, Geophysics, Geosystems 8, Q04I16, doi:10.1029/2006GC001444.

Reagan, M. K., Ishizuka, O., Stern, R. J., Kelley, K. A., Ohara, Y., Blichert-Toft J., Bloomer, S. H., Cash, J., Fryer, P., Hanan, B. B., Hickey-Vargas, R., Ishii, T., Kimura, J. I., Peate, D. W., Rowe, M. C. \& Woods, M. (2010). Fore-arc basalts and subduction initiation in the IzuBonin-Mariana system. Geochemistry, Geophysics, Geosystems 11, Q03X12, doi:10.1029/2009GC002871.

Reagan, M. K., Pearce, J. A., Petronotis, K., Almeev, R. R., Avery, A. J., Carvallo, C., Chapman, T., Christeson, G. L., Ferré, E. C., Godard, M., Heaton, D. E., Kirchenbaur, M., Kurz, W., Kutterolf, S., Li, H., Michibayashi, K., Morgan, S., Nelson, W. R., Prytulak, J., Python, M., Robertson, A. H. F., Ryan, J. G., Sager, W. W., Sakuyama, T., Shervais, J. W., Shimizu, K. \& Whattam, S.A. (2017). Subduction initiation and ophiolite crust: new insights from IODP drilling. International Geology Review 59, DOI: 10.1080/00206814.2016.1276482.

Reagan, M. K., Heaton, D. E., Schmitz, M. D., Pearce, J. A., Shervais, J. W. \& Koppers, A. A. P. (2019). Forearc ages reveal extensive shortlived and rapid seafloor spreading following subduction initiation. Earth and Planetary Science Letters 506, 520-529.

Ribeiro, J., Ishizuka, O., Lee, C-T. A. \& Girard, G. (2019). Evolution and maturation of the nascent Mariana arc. Earth and Planetary Science Letters 530, https://doi.org/10.1016/j.eps1.2019.115912. 
878 and geochemistry of West Philippine Basin basalts and early Palau-Kyushu arc volcanic 879 clasts from ODP Leg 195, Site 1201D: Implications for the early history of the Izu-Bonin880 Mariana Arc. Journal of Petrology 47, 277-299.

881 Seton, M., Flament, N., Whittaker, J., Müller, R. D., Gurnis, M. \& Bower, D. J. (2015). Ridge 882 subduction sparked reorganization of the Pacific plate-mantle system 60-50 million years 883 ago. Geophysical Research Letters 42, 1732-1740.

884 Shervais, J. W., Reagan, M., Haugen, E., Almeev, R. R., Pearce, J. A., Prytulak, J., Ryan, J. G., 885 Whattam, S. A., Godard, M., Chapman, T., Li, H., Kurz, W., Nelson, W., Heaton, D., 886 Kirchenbaur, M., Shimizu, K., Sakuyama, T., Li, Y. \& Vetter, S. K. (2019). Magmatic 887 response to subduction initiation: Part 1. Fore-arc basalts of the Izu-Bonin arc from IODP 888 Expedition 352. Geochemistry, Geophysics, Geosystems 20, 889 https://doi.org/10.1029/2018GC007731.

890 Steiger, R. H. \& Jäger, E. (1977). Subcommision on Geochronology: convention on the use of 891 decay constants in geo- and cosmochronology. Earth and Planetary Science Letters 36, 359892

893 Stern, R. J. \& Bloomer, S. H. (1992). Subduction zone infancy: examples from the Eocene Izu894 Bonin-Mariana and Jurassic California Arcs. Geological Society of America Bulletin 104, 895 1621-1636.

896 Stern, R. J. (2004). Subduction Initiation: Spontaneous and Induced. Earth and Planetary 897 Science Letters 226, 275-292.

898 Stern, R. J., Reagan, M., Ishizuka, O., Ohara, Y. \& Whattam, S. (2012). To understand 899 subduction initiation, study forearc crust; to understand forearc crust, study ophiolites. $900 \quad$ Lithosphere 4, 469-483.

901 Straub, S. M., Goldstein, S. L., Class, C. \& Schmidt, A. (2009). Mid-ocean-ridge basalt of 902 Indian type in the northwest Pacific Ocean basin. Nature Geoscience 2, 286-289.

903 Straub, S. M., Woodhead, J. D. \& Arculus, R. J. (2015). Temporal evolution of the Mariana 904 Arc: mantle wedge and subducted slab controls revealed with a tephra perspective. Journal 905 of Petrology 56, 409-439.

906 Tanaka, T., Togashi, S., Kamioka, H., Amakawa, H., Kagami, H., Hamamoto, T., Yuhara, M., 907 Orihashi, Y., Yoneda, S., Shimizu, H., Kunimaru, T., Takahashi, K., Yanagi. T., Nakano, T., 908 Fujimaki, H., Shinjo, R., Asahara. Y., Tanimizu, M. \& Dragusanu, C. (2000). JNdi-1: a 909 neodymium isotopic reference in consistency with LaJolla neodymium. Chemical Geology 910 168, 279-281. 
911 Taylor, B. (1992). Rifting and the volcanic-tectonic evolution of the Izu-Bonin-Mariana Arc. 912 In: Taylor B. \& Fujioka K. et al., (eds) Proceedings of the Ocean Drilling Program, Scientific 913 Results 126, 627-651.

914 Taylor, R. N., Nesbitt, R. W., Vidal, P., Harmon, R. S., Auvray, B. \& Croudace, I. W. (1994). 915 Mineralogy, chemistry, and genesis of the Boninite Series Volcanics, Chichijima, Bonin 916 Islands, Japan. Journal of Petrology 35, 577-617.

917 Taylor, R. N. \& Nesbitt, R. W. (1995). Arc volcanism in an extensional regime at the initiation 918 of subduction: A geochemical study of Hahajima, Bonin Islands, Japan. In: Smellie, J. (ed) 919 Volcanism associated with Extension at Consuming Plate Margins. Geological Society, 920 London, Special Publications 81, 115-134.

921 Taylor, R. N. \& Nesbitt, R. W. (1998). Isotopic characteristics of subduction fluids in an intra922 oceanic setting, Izu-Bonin Arc, Japan. Earth and Planetary Science Letters 164, 79-98.

Taylor, R. N., Ishizuka, O., Michalik, A., Milton, J. A. \& Croudace, I. W. (2015). Evaluating 924 the precision of $\mathrm{Pb}$ isotope measurement by mass spectrometry. Journal of Analytical Atomic Spectrometry 30, 198-213.

Thirlwall, M. E. (1991). Long-term reproducibility of multicollector $\mathrm{Sr}$ and $\mathrm{Nd}$ isotope ratio 927 analysis. Chemical Geology (Isotope Geoscience Section) 94, 85-104.

Uchiumi, S. \& Shibata, K. (1980). Errors in K-Ar age determination. Bulletin of Geological 929 Survey of Japan 31, 267-273 (in Japanese with English abstract).

930

Umino, S. (1985). Volcanic geology of Chichijima, the Bonin Islands (Ogasawara Islands). The 931 Journal of the Geological Society of Japan 91, 505-523.

Umino, S. \& Nakano, S. (2007). Geology of the Chichijima Retto District. Quadrangle Series, 1:50000, Geological Survey of Japan, AIST, 63p (in Japanese with English abstract).

Umino, S., Nakano, S., Ishizuka, O. \& Komazawa, M. (2009). Geological Map of Japan 1:200,000, Ogasawara Shoto (in Japanese). Geological Survey of Japan, AIST.

Umino, S., Kitamura, K., Kanayama, K., Tamura, A., Sakamoto, N., Ishizuka, O. \& Arai, S. (2015). Thermal and chemical evolution of the subarc mantle revealed by spinel-hosted melt inclusions in boninite from the Ogasawara (Bonin) Archipelago. Geology 43, 151-154.

Umino, S., Ishizuka, O. \& Kanayama, K. (2016). Geology of the Hahajima Retto district. Quadrangle Series, 1:50000, Geological Survey of Japan, AIST, 46p (in Japanese with English abstract). 
942 Umino, S., Kanayama, K., Kitamura, K., Tamura, A., Ishizuka, O., Senda, R. \& Arai, S. (2018). 943 Did boninite originate from the heterogeneous mantle with recycled ancient slab? Island Arc 944 27, e12221, doi: 10.1111/iar.12221.

945 Willbold, M. \& Stracke, A. (2006). Trace element composition of mantle end-members: 946 Implications for recycling of oceanic and upper and lower continental crust, Geochemistry 947 Geophysics Geosystems 7, Q04004, doi:10.1029/2005GC001005.

948 Woodhead J., Hergt J., Davidson J. P. \& Eggins S. M. (2001). Hafnium isotope evidence 949 for 'conservative' element mobility during subduction zone processes. Earth and Planetary $950 \quad$ Science Letters 192, 331-346.

951 Wu, J., Suppe, J., Lu, R. \& Kanda, R. (2016). Philippine Sea and East Asian plate tectonics 952 since $52 \mathrm{Ma}$ constrained by new subducted slab reconstruction methods. Journal of 953 Geophysical Research121, 4670-4741.

954 Yogodzinski, G., Bizimis, M., Hickey-Vargas, R., McCarthy, A., Hocking, B. D., Savov, I. P., 955 Ishizuka, O. \& Arculus, R. (2018). Implications of Eocene-age Philippine Sea and Forearc 956 basalts for initiation and early history of the Izu-Bonin-Mariana arc. Geochimica et 957 Cosmochimica Acta 228, 136-156.

958 York, D. (1969). Least squares fitting of a straight line with correlated errors. Earth and 959 Planetary Science Letters 5, 320-324.

960 Zindler, A. \& Hart, S. (1986). Chemical geodynamics. Annual Review of Earth and Planetary 961 Sciences 14, 493-571. 962 963 964 965 966 967 968 969 970 971 972 973 974 


\section{$975 \quad$ Figure captions}

976

977

978

979

980

981

982

983

984

985

986

987

988

989

990

991

992

993

994

995

996

997

998

999

1000

1001

1002

1003

1004

1005

1006

1007

Fig. 1. a) Overview of the bathymetry of the Izu-Bonin-Mariana arc and location of the Bonin Ridge, b) Location of the Bonin Islands with bathymetric map of the Bonin Ridge. Locations of studied islands and submarine sampling stations are shown with the symbols used in the geochemical plots. (Ishizuka et al., 2006a, 2011a; Reagan et al., 2017). Fig. 1a and 1b are modified from Ishizuka et al. (2011a). Distribution of each rock type is indicated by the black dashed lines.

Fig. 2. Schematic stratigraphic section and overall chemostratigraphic variation through the Bonin Ridge forearc crust. Rock types and symbols shown in this figure remain consistent through the geochemical plots in all figures. Average content of $\mathrm{SiO}_{2}, \mathrm{CaO}$ and $\mathrm{TiO}_{2}$ projected to $8 \% \mathrm{MgO}$ ( $\mathrm{Si} 8, \mathrm{Ca} 8$ and $\mathrm{Ti} 8)$ for each stratigraphic unit are shown in the columns to the right.

Fig. $3 .{ }^{40} \mathrm{Ar} /{ }^{39} \mathrm{Ar}$ age spectra and $\mathrm{Ca} / \mathrm{K}$ plots for groundmass samples from the Bonin Islands.

Fig. 4. Major element composition of volcanic rocks from the Bonin Islands. Variation of $\mathrm{SiO}_{2}$ with a) $\mathrm{MgO}$, b) $\mathrm{FeO}^{*}\left(\mathrm{FeO}^{\text {total }}\right) / \mathrm{MgO}$ (Line distinguishing the tholeiitic and calc-alkaline field is from Miyashiro (1974)), and variation of $\mathrm{MgO}$ with c) $\mathrm{TiO}_{2}$, and d) $\mathrm{CaO}$. Data of boninites from IODP Exp. 352 are from Li et al. (2019).

Fig. 5. Incompatible trace element ratios for the Bonin Islands. Variation of a) $\mathrm{Ce} / \mathrm{Pb}, \mathrm{b}$ ) $\mathrm{Ba} / \mathrm{Nb}, \mathrm{c}$ ) $\mathrm{Th} / \mathrm{Ce}$, d) La/Sm, e) Dy/Yb with $\mathrm{SiO}_{2}$ in wt $\%$, f) Sm/Zr with $\mathrm{Sm}$ in ppm and g) $\mathrm{Nb} / \mathrm{Zr}$ with $\mathrm{MgO}$ in wt\%. Data of boninites from IODP Exp. 352 are from Li et al. (2019). Symbols as in Fig. 4. Average trace element ratios for all normal MORB (Gale et al., 2013) are shown. Dashed line with arrow in each plot (where the partition coefficient data is available) qualitatively show effect of fractionation of amphibole as a guide based on partition coefficients for basalt and andesite compiled in the GERM data base (https://earthref.org).

Fig. 6. Radiogenic isotope variation for the Bonin Islands plotted with potential slab and mantle components. a) $\Delta^{207} \mathrm{~Pb} / 204 \mathrm{~Pb}$ vs. ${ }^{206} \mathrm{~Pb} /{ }^{204} \mathrm{~Pb}$, b) $\Delta^{208} \mathrm{~Pb} /{ }^{204} \mathrm{~Pb}$ vs. ${ }^{206} \mathrm{~Pb} / 204 \mathrm{~Pb}$, c) $\Delta^{207} \mathrm{~Pb} / 204 \mathrm{~Pb}$ vs. ${ }^{207} \mathrm{~Pb} / 204 \mathrm{~Pb}$, d) $\varepsilon \mathrm{Nd}$ vs. ${ }^{87} \mathrm{Sr} /{ }^{86} \mathrm{Sr}$, e) $\varepsilon \mathrm{Nd}$ vs. ${ }^{206} \mathrm{~Pb} / 204 \mathrm{~Pb}$, f) $\varepsilon \mathrm{Hf}$ vs. $\varepsilon \mathrm{Nd}$. Assumed compositions of subducting igneous crust and sediment are shown (Table S7). Pelagic sediment outboard of Izu-Bonin arc: Plank et al. (2007), Pelagic sediment outboard of Mariana arc: Plank \& Langmuir (1998), Subducting altered igneous Pacific crust: Hauff et al. (2003), volcaniclastic sediment derived from HIMU oceanic islands: Plank \& Langmuir (1998). Philippine Sea MORB: Hickey-Vargas (1991, 1998), Savov et al. (2006), Ishizuka et al. (2009, 2010, 2011b, 2013). Pacific MORB data was compiled from the Earthchem data base 
1008 (https://www.earthchem.org). Least squares regression lines are shown in $\mathrm{Pb}$ isotopic plots for 1009 some rock types with sufficient data. Symbols are as on Fig. 4. Isotopic ratios plotted in these 1010 figures are not age-corrected.

1011 Fig. 7. Isotope versus trace element ratio plots for the Bonin Islands volcanics. Data sources 1012 are the same as for Figure 6. Least squares regression lines are shown in panel b. Symbols as 1013 in Fig. 4.

1014 Fig. 8. $\mathrm{Nb} / \mathrm{Zr}$ vs. ${ }^{206} \mathrm{~Pb} /{ }^{204} \mathrm{~Pb}$ plot. A vector towards volcaniclastic sediment derived from 1015 HIMU oceanic islands is shown (Plank \& Langmuir, 1998). Symbols as in Fig. 4.

1016 Fig. 9. Schematic diagram showing the progressive variation in the nature of the slab flux 1017 following subduction initiation. a) Chichijima/Mukojima group, 48-45 Ma: shallow melting $1018(\sim 35 \mathrm{~km})$ with flux from pelagic sediment and Pacific Ocean igneous crust added to a 1019 harzburgitic mantle; b) Mikazukiyama group, 45-44 Ma: melting at $\sim 35 \mathrm{~km}$, slightly further 1020 from the trench, flux from HIMU volcaniclastic sediment added to a less depleted mantle 1021 source; c) Hahajima group, $<45 \mathrm{Ma}$ : deeper melting ( $\sim 60 \mathrm{~km})$ further from the trench with flux 1022 from Pacific Ocean crust added to an upwelling, more fertile mantle source. d) Schematic 1023 diagram showing the estimated scale and duration of flux components on the subducting slab. 

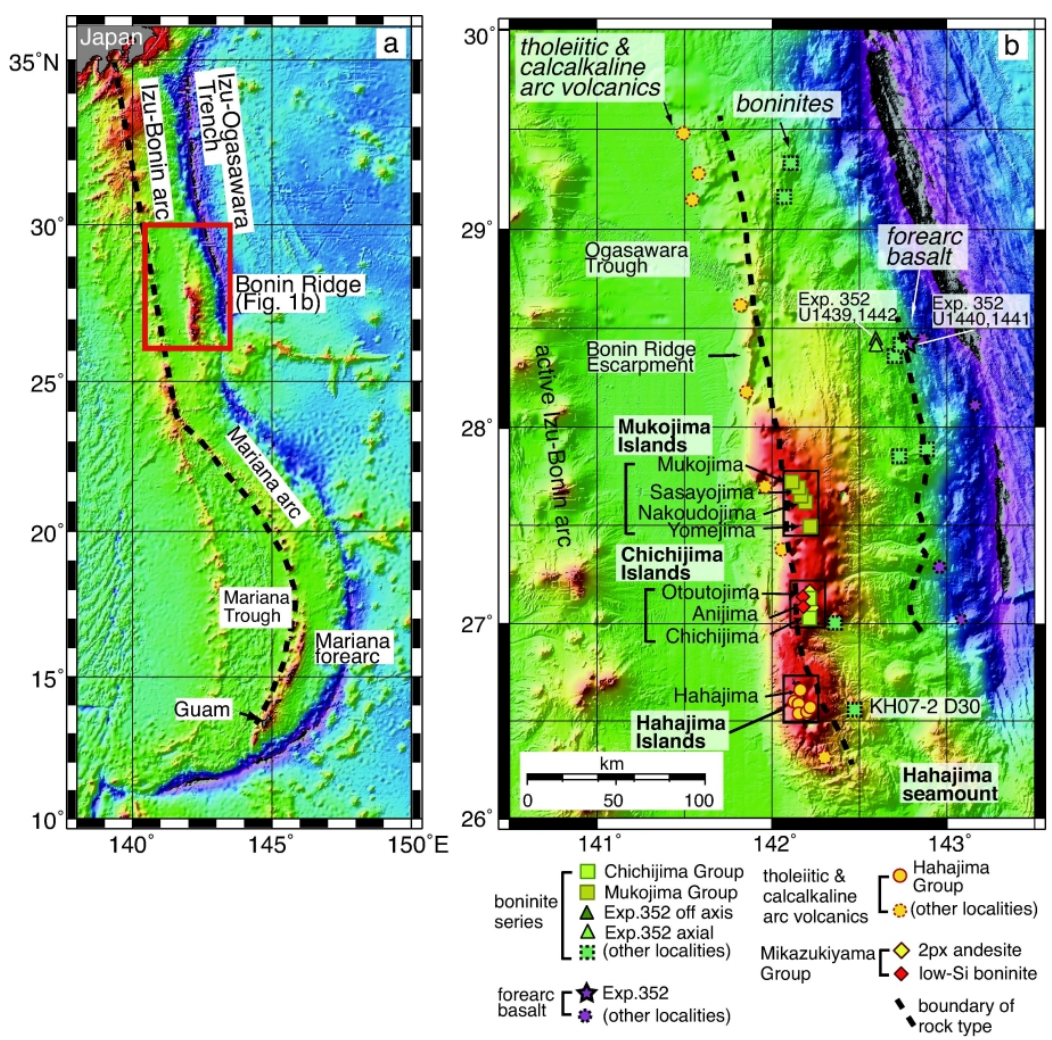

Fig. 1 Ishizuka et al.

Fig. 1. a) Overview of the bathymetry of the Izu-Bonin-Mariana arc and location of the Bonin Ridge, b) Location of the Bonin Islands with bathymetric map of the Bonin Ridge. Locations of studied islands and submarine sampling stations are shown with the symbols used in the geochemical plots. (Ishizuka et al., 2006a, 2011a; Reagan et al., 2017). Fig. 1a and 1b are modified from Ishizuka et al. (2011a). Distribution of each rock type is indicated by the black dashed lines.

$$
146 \times 211 \mathrm{~mm}(600 \times 600 \mathrm{DPI})
$$


Fig. 2. Schematic stratigraphic section and overall chemostratigraphic variation through the Bonin Ridge forearc crust. Rock types and symbols show in this figure remain consistent through the geochemical plots in all figures. Average content of $\mathrm{SiO} 2, \mathrm{CaO}$ and $\mathrm{TiO} 2$ projected to $8 \% \mathrm{MgO}$ (Si8, $\mathrm{Ca} 8$ and $\mathrm{Ti} 8$ ) for each stratigraphic unit are shown in the columns to the right.

$196 \times 252 \mathrm{~mm}(600 \times 600 \mathrm{DPI})$ 

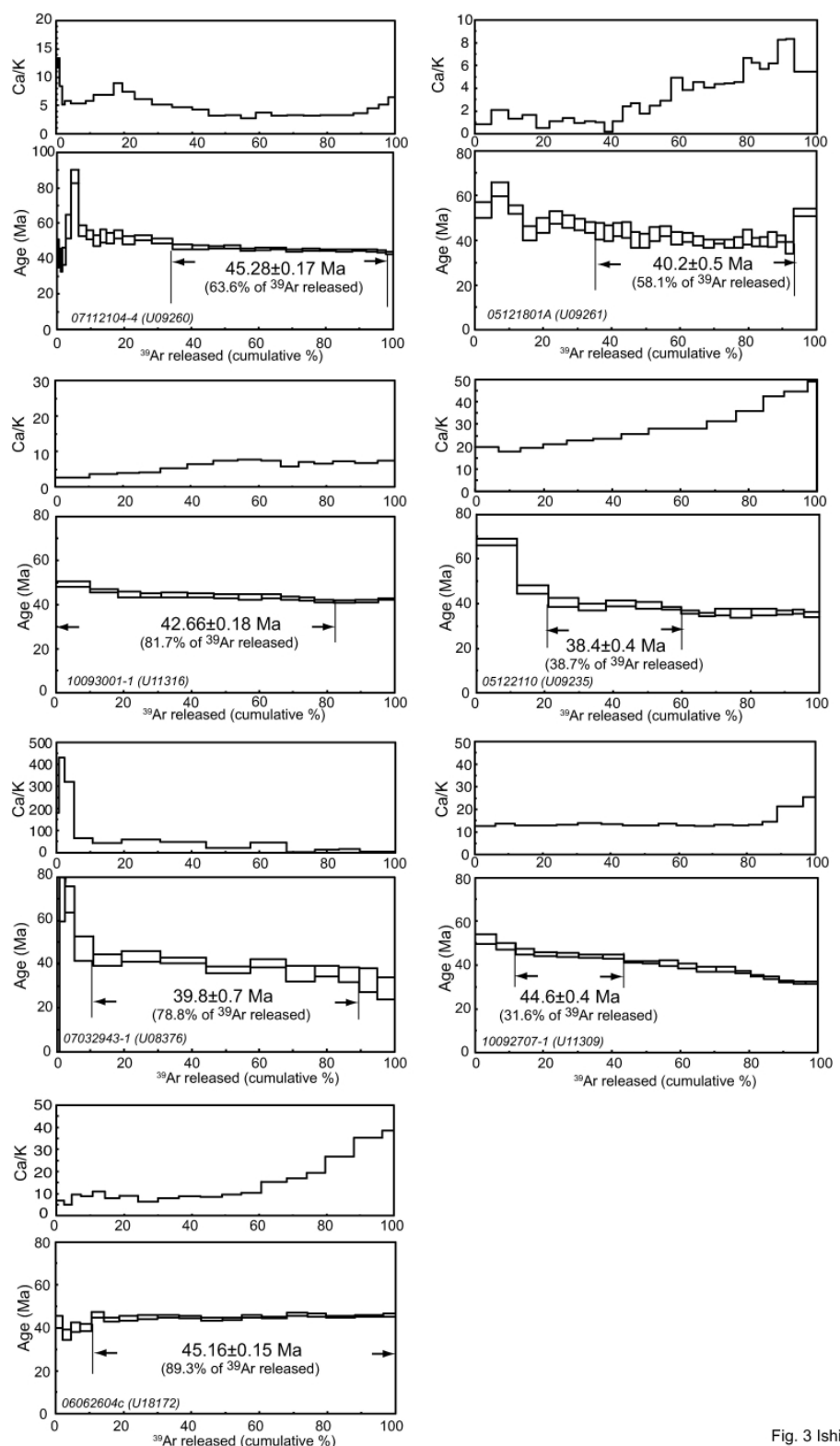

Fig. 3 Ishizuka et al.

Fig. 3. 40Ar/39Ar age spectra and $\mathrm{Ca} / \mathrm{K}$ plots for groundmass samples from the Bonin Islands.

$177 \times 281 \mathrm{~mm}(600 \times 600 \mathrm{DPI})$ 

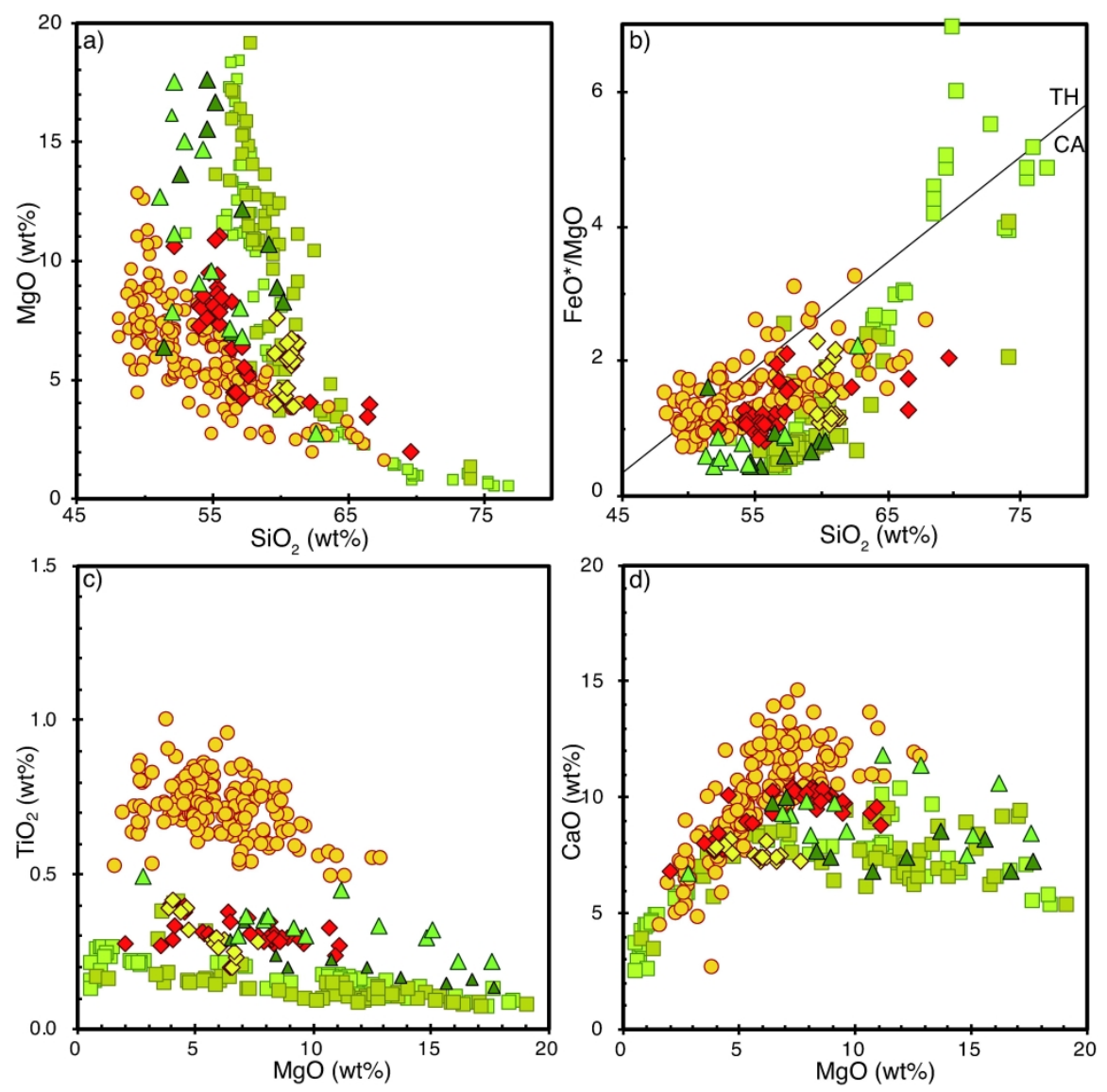

\begin{tabular}{|c|c|c|}
\hline 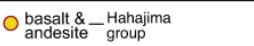 & $\square$ high-Si boninite \&_Chichijima & $\Delta_{\text {boninite }}^{\text {Exp.352 off-axis }}$ \\
\hline $\left.\begin{array}{l}\text { low-Si boninite } \\
22 \mathrm{px} \text { andesite }\end{array}\right]_{\text {group }}^{\text {Mikazukiyama }}$ & $\square$ high-Si boninite \&_Mukojima & $\Delta{ }_{\text {boninite }}^{\text {Exp.352 axial }}$ \\
\hline
\end{tabular}

Fig. 4 Ishizuka et al.

Fig. 4. Major element composition of volcanic rocks from the Bonin Islands. Variation of $\mathrm{SiO} 2$ with a) MgO, b) $\mathrm{FeO} *(\mathrm{FeOtotal}) / \mathrm{MgO}$ (Line distinguishing the tholeiitic and calc-alkaline field is from Miyashiro (1974)), and variation of $\mathrm{MgO}$ with c) $\mathrm{TiO}_{2}$, and d) $\mathrm{CaO}$. Data of boninites from IODP Exp. 352 are from Li et al. (2019).

$186 \times 253 \mathrm{~mm}(600 \times 600 \mathrm{DPI})$ 

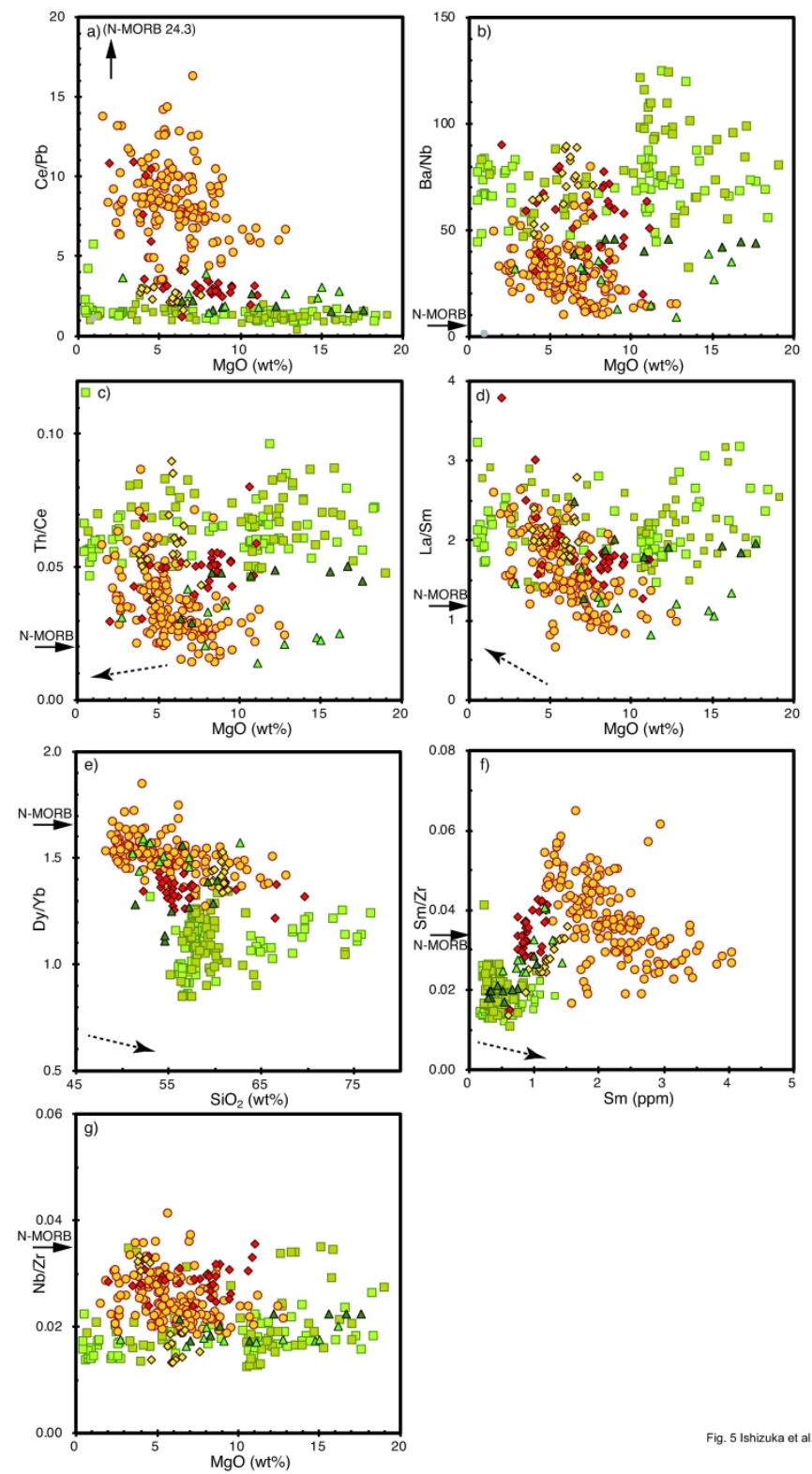

Fig. 5 Incompatible trace element ratios for the Bonin Islands. Variation of a) $\mathrm{Ce} / \mathrm{Pb}, \mathrm{b}) \mathrm{Ba} / \mathrm{Nb}, \mathrm{c}) \mathrm{Th} / \mathrm{Ce}$, d) $\mathrm{La} / \mathrm{Sm}, \mathrm{e}$ ) Dy/Yb with $\mathrm{SiO} 2$ in wt\%, f) Sm/Zr with Sm in ppm and g) Nb/Zr with MgO in wt\%. Data of boninites from IODP Exp. 352 are from Li et al. (2019). Symbols as in Fig. 4. Average trace element ratios for all normal MORB (Gale et al., 2013) are shown. Dashed line with arrow in each plot (where the partition coefficient data is available) qualitatively show effect of fractionation of amphibole as a guide based on partition coefficients for basalt and andesite compiled in the GERM data base (https://earthref.org).

$160 \times 289 \mathrm{~mm}(600 \times 600 \mathrm{DPI})$ 

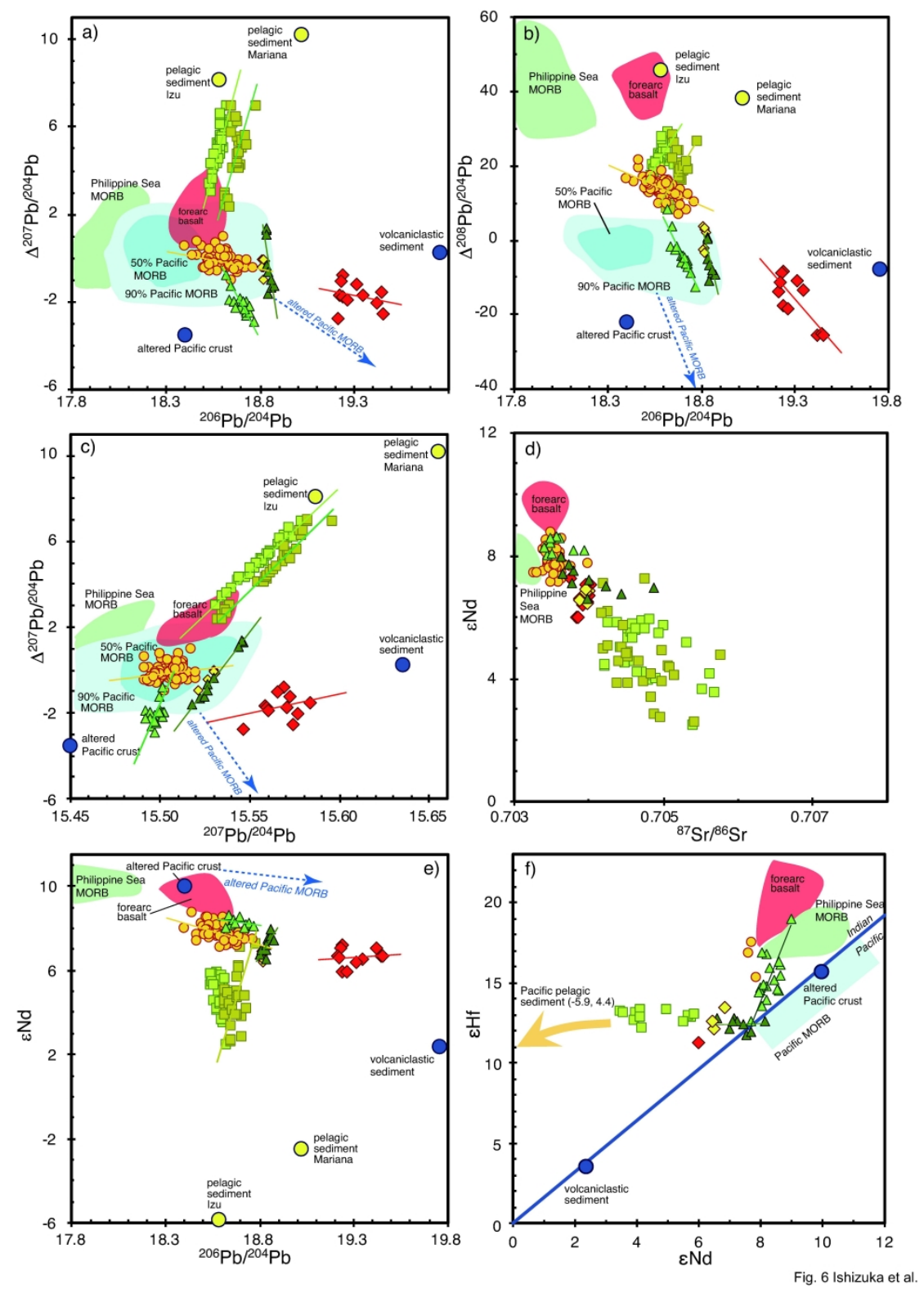

Fig. 6. Radiogenic isotope variation for the Bonin Islands plotted with potential slab and mantle components. a) $\Delta 207 \mathrm{~Pb} / 204 \mathrm{~Pb}$ vs. $206 \mathrm{~Pb} / 204 \mathrm{~Pb}$, b) $\Delta 208 \mathrm{~Pb} / 204 \mathrm{~Pb}$ vs. $206 \mathrm{~Pb} / 204 \mathrm{~Pb}$, c) $\Delta 207 \mathrm{~Pb} / 204 \mathrm{~Pb}$ vs. $207 \mathrm{~Pb} / 204 \mathrm{~Pb}$, d) $\varepsilon N d$ vs. $87 \mathrm{Sr} / 86 \mathrm{Sr}$, e) $\varepsilon N d$ vs. $206 \mathrm{~Pb} / 204 \mathrm{~Pb}, \mathrm{f}) \varepsilon \mathrm{Hf}$ vs. $\varepsilon N d$. Assumed compositions of subducting igneous crust and sediment are shown (Table S7). Pelagic sediment outboard of Izu-Bonin arc: Plank et al. (2007),

Pelagic sediment outboard of Mariana arc: Plank \& Langmuir (1998), Subducting altered igneous Pacific crust: Hauff et al. (2003), volcaniclastic sediment derived from HIMU oceanic islands: Plank \& Langmuir (1998). Philippine Sea MORB: Hickey-Vargas (1991, 1998), Savov et al. (2006), Ishizuka et al. (2009, 2010, 2011b, 2013). Pacific MORB data was compiled from the Earthchem data base

(https://www.earthchem.org). Least squares regression lines are shown in $\mathrm{Pb}$ isotopic plots for some rock types with sufficient data. Symbols are as on Fig. 4. Isotopic ratios plotted in these figures are not agecorrected.

\section{$205 \times 289 m m(600 \times 600$ DPI $)$}



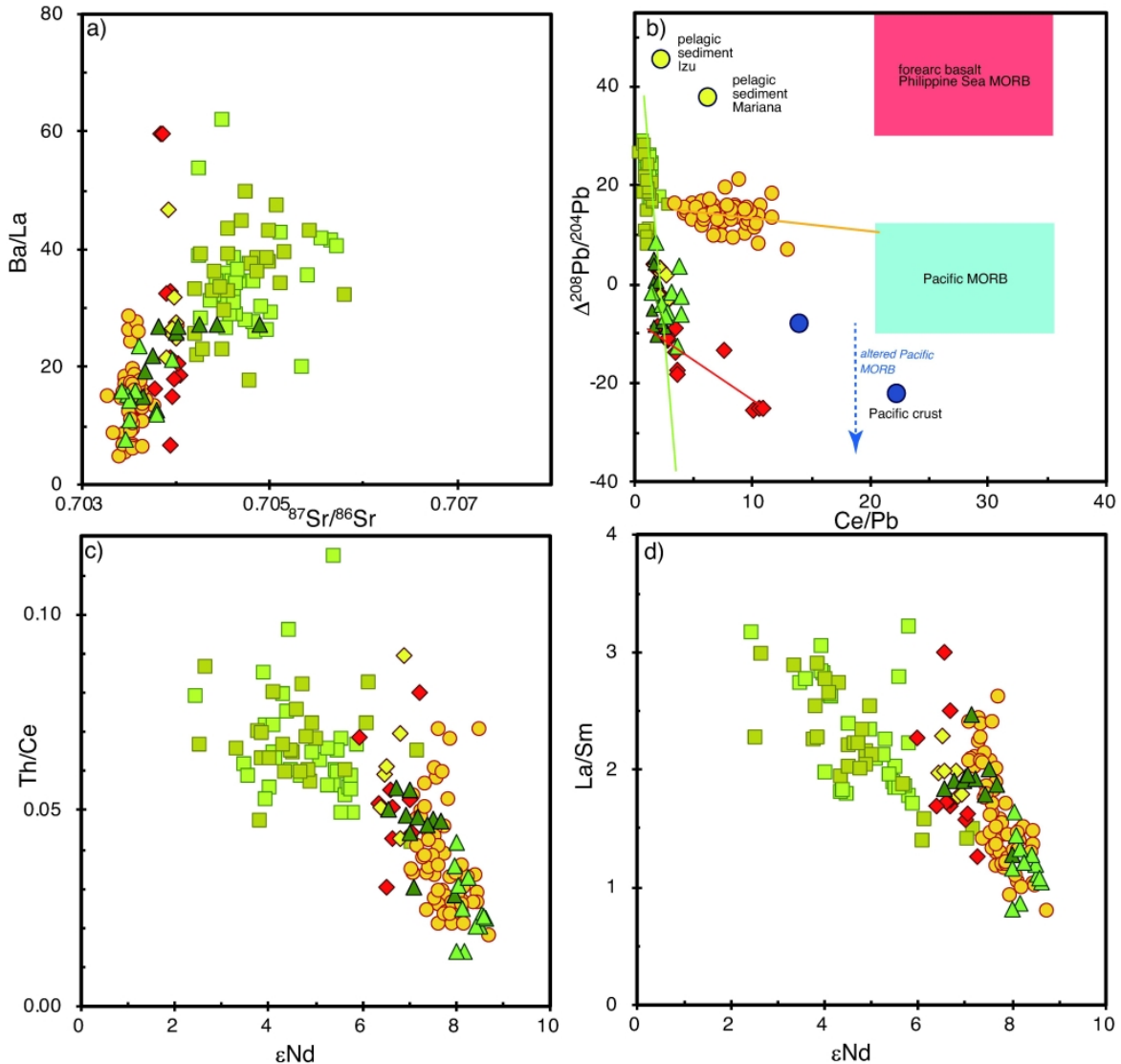

Fig. 7 Ishizuka et al.

Fig. 7. Isotope versus trace element ratio plots for the Bonin Islands volcanics. Data sources are the same as for Figure 6. Isotope versus trace element ratio plots for the Bonin Islands volcanics. Data sources are the same as for Figure 6. Least squares regression lines are shown in panel b. Symbols as in Fig. 4.

$202 \times 271 \mathrm{~mm}(600 \times 600 \mathrm{DPI})$ 


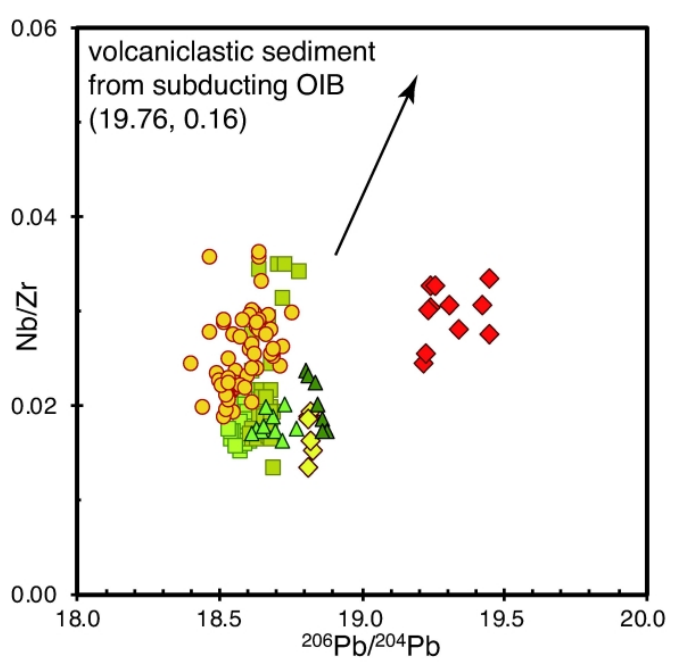

Fig. 8 Ishizuka et al.

Fig. 8. $\mathrm{Nb} / \mathrm{Zr}$ vs. $206 \mathrm{~Pb} / 204 \mathrm{~Pb}$ plot. A vector towards volcaniclastic sediment derived from HIMU oceanic islands is shown (Plank \& Langmuir, 1998). Symbols as in Fig. 4.

$168 \times 235 \mathrm{~mm}(600 \times 600 \mathrm{DPI})$ 

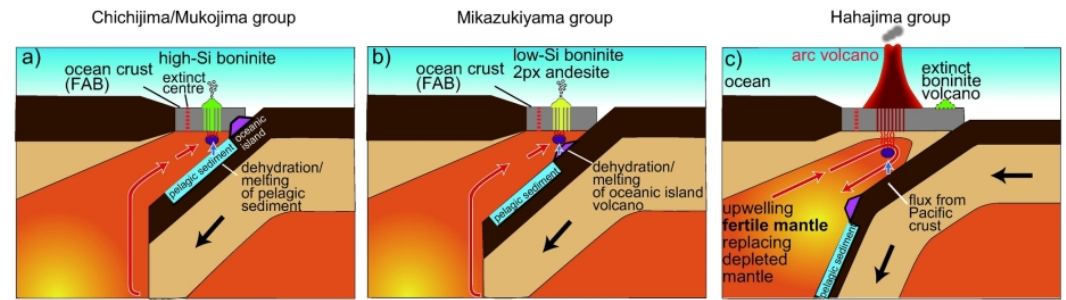

d) $\begin{aligned} & \text { Timing at } \\ & \text { subarc location }\end{aligned}$

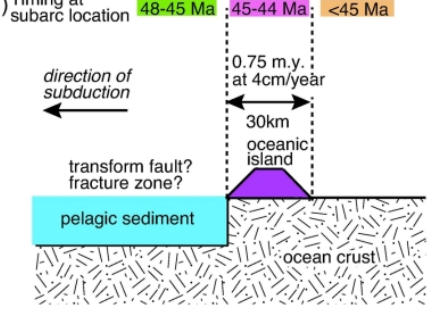

Fig. 9. Schematic diagram showing the progressive variation in the nature of the slab flux following subduction initiation. a) Chichijima/Mukojima group, 48-45 Ma: shallow melting ( $35 \mathrm{~km}$ ) with flux from pelagic sediment and Pacific Ocean igneous crust added to a harzburgitic mantle; b) Mikazukiyama group, 45-44 Ma: melting at $\sim 35 \mathrm{~km}$, slightly further from the trench, flux from HIMU volcaniclastic sediment added to a less depleted mantle source; c) Hahajima group, <45 Ma: deeper melting ( $\sim 60 \mathrm{~km})$ further from the trench with flux from Pacific Ocean crust added to an upwelling, more fertile mantle source. d) Schematic diagram showing the estimated scale and duration of flux components on the subducting slab.

$$
187 \times 258 \mathrm{~mm}(300 \times 300 \mathrm{DPI})
$$


Table 1 Results of ${ }^{40} \mathrm{Ar} /{ }^{39} \mathrm{Ar}$ dating of volcanic rocks from the Bonin islands.

\begin{tabular}{|c|c|c|c|c|c|c|c|c|c|}
\hline \multirow{2}{*}{$\begin{array}{c}\text { Analysis } \\
\text { No. }\end{array}$} & \multirow[t]{2}{*}{ Sample No. } & \multirow[t]{2}{*}{ Name of island } & \multirow[t]{2}{*}{ steps } & \multirow{2}{*}{$\begin{array}{c}\text { Total gas age }( \pm 1 \sigma) \\
\text { integrated age } \\
(\mathrm{Ma}) \\
\end{array}$} & \multicolumn{4}{|c|}{ Plateau age $( \pm 1 \sigma)$} & \multirow[b]{2}{*}{$\begin{array}{c}\text { fraction of } \\
{ }^{39} \operatorname{Ar}(\%) \\
\end{array}$} \\
\hline & & & & & $\begin{array}{l}\text { weighted average } \\
(\mathrm{Ma}) \\
\end{array}$ & $\begin{array}{c}\text { inv. isochron } \\
\text { age (Ma) } \\
\end{array}$ & $\begin{array}{l}{ }^{40} \mathrm{Ar} /{ }^{36} \mathrm{Ar} \\
\text { intercept } \\
\end{array}$ & MSWD & \\
\hline \multicolumn{10}{|c|}{ Hahajima Island Group } \\
\hline 09260 & 07112104-4 & Hahajima & 30 & $48.2 \pm 0.3$ & $45.28 \pm 0.17$ & $43.9 \pm 1.6$ & $314 \pm 20$ & 1.32 & 63.6 \\
\hline 09261 & $05121801 \mathrm{~A}$ & Hahajima & 31 & $45.2 \pm 0.5$ & $40.2 \pm 0.5$ & $39.7 \pm 4.5$ & $296 \pm 6$ & 0.90 & 58.1 \\
\hline 11316 & $10093001-1$ & Hahajima & 15 & $44.16 \pm 0.25$ & $42.66 \pm 0.18$ & $41.4 \pm 0.5$ & $592 \pm 85$ & 1.16 & 81.7 \\
\hline 09235 & 05122110 & Meijima & 15 & $42.0 \pm 0.4$ & $38.4 \pm 0.4$ & $35.2 \pm 2.1$ & $340 \pm 28$ & 0.73 & 38.7 \\
\hline 08376 & 07032943-1 & Imoutojima & 14 & $40.2 \pm 0.9$ & $39.8 \pm 0.7$ & $38.7 \pm 1.2$ & $334 \pm 26$ & 1.18 & 78.8 \\
\hline 11309 & $10092707-1$ & Mukoujima & 19 & $41.2 \pm 0.3$ & $44.6 \pm 0.4$ & $42.8 \pm 1.3$ & $348 \pm 37$ & 0.57 & 31.6 \\
\hline \multicolumn{10}{|c|}{ low-Si boninite from Chichijima Island Group } \\
\hline 18172 & $06062604 \mathrm{C}$ & Otoutojima & 19 & $44.57 \pm 0.19$ & $45.16 \pm 0.15$ & $45.3 \pm 0.3$ & $292 \pm 6$ & 1.24 & 89.3 \\
\hline
\end{tabular}

inv. isochron age: inverse isochron age.

MSWD: mean square of weighted deviates $\left((\mathrm{SUMS} /(\mathrm{n}-2))^{\wedge} 0.5\right)$ in York (1969).

Integrated ages were calculated using sum of the total gas released.

$\lambda_{b}=4.962 \times 10^{-10} y^{-1}, \lambda_{e}=0.581 \times 10^{-10} y^{-1},{ }^{40} K / K=0.01167 \%$ (Steiger \& Jager 1977).

Atmospheric ${ }^{40} \mathrm{Ar} /{ }^{36} \mathrm{Ar}: 295.5$ 